\title{
The evolution of the Izu Bonin - Mariana volcanic arcs (NW Pacific) in terms of major element chemistry
}

\author{
Susanne M. Straub \\ GEOMAR Forschungszentrum an der Christian-Albrechts Universität zu Kiel, Wischhofstrasse 1-3, 24148 Kiel, \\ Federal Republic of Germany (sstraub@geomar.de)
}

[1] New and published analyses of major element oxides $\left(\mathrm{SiO}_{2}, \mathrm{TiO}_{2}, \mathrm{Al}_{2} \mathrm{O}_{3}, \mathrm{FeO}\right.$, $\mathrm{MnO}, \mathrm{MgO}, \mathrm{CaO}$, $\mathrm{K}_{2} \mathrm{O}, \mathrm{Na}_{2} \mathrm{O}$ and $\mathrm{P}_{2} \mathrm{O}_{5}$ ) from the central Izu Bonin and Mariana arcs (IBM) were compiled in order to investigate the evolution of the IBM in terms of major elements since arc inception at $\sim 49$ million years ago. The database comprises $\sim 3500$ volcanic glasses of distal tephra fallout and $\sim 500$ lava samples, ranging from the Quaternary to mid-Eocene in age. The data were corrected to $4 \mathrm{wt} \% \mathrm{MgO}$ in order to display the highly resolved temporal trends. These trends show that the IBM major elements have always been "arc-like" and clearly distinct from N-MORB. Significant temporal variations of some major element oxides are apparent. The largest variations are displayed by $\mathrm{K}_{4.0}$. The data support a model wherein the $\mathrm{K}_{2} \mathrm{O}$ variability is caused by the addition of slab component with strongly differing $\mathrm{K}_{2} \mathrm{O}$ contents to a fairly depleted subarc mantle; variable extents of melting, or mantle heterogeneity, appear to play a negligible role. The other major element oxides are controlled by the composition and processes of the subarc mantle wedge. The transition from the boninitic and tholeiitic magmatism of the Eocene and Oligocene to the exclusively tholeiitic magmatism of the Neogene IBM is proposed to reflect a change in the composition of the subarc mantle wedge. The early boninitic magmas originate from an ultra-depleted subarc mantle, that is residual to either the melting of E-MORB mantle, or of subcontinental lithospheric mantle. During the Eocene and Oligocene, this residual mantle is gradually replaced by Indian MORB mantle advected from the backarc regions. The Indian MORB mantle is more radiogenic in $\mathrm{Nd}$ isotope ratios but also more fertile with respect to major and trace elements. Therefore the Neogene tholeiites have higher $\mathrm{Al}_{2} \mathrm{O}_{3}$ and $\mathrm{TiO}_{2}$ contents and lower mg\# numbers at given $\mathrm{SiO}_{2}$ content. After the subarc mantle replacement was complete in the late Oligocene or early Miocene, the Neogene IBM entered a "steady state" that is characterized by the continuous advection of Indian MORB mantle from the reararc, which is fluxed by fluids and melt components from slab. The thickness of the IBM crust must have grown with time, but any effects of crustal thickening on the major element chemistry of the IBM magmas appear to be minor relative to the compositional changes that are related to source composition. Therefore next to the processes of melting, the composition of the mantle sources must play a major role in creating substantiative heterogeneities in the major element chemistry of the arc crust.

Components: 14,516 words, 19 figures, 4 tables.

Keywords: Izu Bonin Mariana; tephra; major elements; arc evolution.

Index Terms: 3655 Mineralogy and Petrology: Major element composition; 1020 Geochemistry: Composition of the crust; 1015 Geochemistry: Composition of the core.

Received 8 April 2002; Revised 28 July 2002; Accepted 8 October 2002; Published 19 February 2003.

Straub, S., The evolution of the Izu Bonin - Mariana volcanic arcs (NW Pacific) in terms of major element chemistry, Geochem. Geophys. Geosyst., 4(2), 1018, doi:10.1029/2002GC000357, 2003. 


\section{Introduction}

[2] Determining the fluxes of the major elements from mantle to crust is central to understanding the formation and growth of the continental crust [Gill, 1981; Plank and Langmuir, 1988; Kelemen, 1995; Rudnick, 1995; Prouteau et al., 2001]. Since continental crust is still produced in modern volcanic arcs, these provide 'natural laboratories' in where the crust formation can be studied. Although arc volcanic rocks are commonly summarized as 'andesites' [e.g., Gill, 1981], they display a considerable range in major element chemistry. It is much debated, whether this diversity is controlled by local or regional processes (e.g., crustal differentiation, mantle melting, source composition), or whether it is subject to processes that are operative on a global scale [e.g., Gill, 1981; Plank and Langmuir, 1988; Kelemen, 1995]. Based on a compilation of arc volcanic rocks world-wide, Plank and Langmuir [1988] suggested a fundamental dependence between the $\mathrm{Na}_{2} \mathrm{O}$ and $\mathrm{CaO}$ contents of arc volcanic rocks and the extent of melting in the subarc mantle. However, despite the compelling simplicity of this model, and its fundamental implications with respect to the rates of crustal growth, it clearly does not account for the entire spectrum of major element compositions [e.g., Taylor and Nesbitt, 1995; Sun and Stern, 2001]. Thus, the challenge remains to better identify the processes that shape the major element chemistry of arc magmas in order to understand better the general processes of arc crust formation and growth.

[3] One possible approach to this problem is investigating the temporal trends of major elements during the lifetime of an arc ( $\sim 20$ to 100 million years). Volcanic arcs are mobile and dynamic systems that are continuously subject to thermal and structural changes [Taylor et al., 1992; Arculus et al., 1995]. How the major elements respond to these changes should provide information on their source reservoirs and generic processes of formation and evolution. The reconstruction of the major element evolution of a volcanic arc requires a coherent, temporally highly resolved record of the arc history. The volcanic glasses contained in distal fallout tephra have shown potential for reconstructing the temporal trends of incompatible trace elements and isotopic tracers [Arculus and Bloomfield, 1992; Lee et al., 1995; Bryant et al., 1999; Straub et al., 2002; Straub and Layne, 2002a; Schmidt, 2001]. However, no effort has been made to use the tephra glasses as source of information with respect to reconstructing the major element history of arcs.

[4] A continuous, temporally highly resolved tephra fallout record exists for the adjacent Izu Bonin and Mariana volcanic arcs (= IBM; NW Pacific; Figure 1) that are active since 49 million years [e.g., Arculus et al., 1995]. In the wake of the DSDP and ODP programs, extensive research has been carried out in the IBM and a general evolutionary framework has been established [e.g., Taylor, 1992; Arculus et al., 1995]. A substantiative amount of bulk rock analytical data is available from the various evolutionary stages of the arcs with which the tephra glasses can be compared (Table 1). Moreover, the impact of crustal differentiation on the major elements is presumably minor owing to the thin crust $(\sim 20-30 \mathrm{~km})$ on which the arcs are constructed. Interestingly, despite the similar evolution, the Izu Bonin and Mariana arcs display considerable variations in trace elements and isotopes through time and space [e.g., Gill et al., 1994; Bryant et al., 1999], demonstrating that different source reservoirs are involved in the magma genesis.

\section{Geological Setting}

[5] Summaries of the geology and the evolution of the IBM can be found elsewhere [Taylor, 1992; Arculus et al., 1995], and only the most relevant facts are re-iterated here. The adjacent Izu Bonin and Mariana arcs are part of the intraoceanic Izu Bonin-Mariana arc/backarc system, that is located in the northwestern Pacific and extends $\sim 2500$ kilometers south of Honshu (Japan) (Figure 1). Subduction initiated in the middle Eocene (49-48 Ma [Taylor, 1992; Cosca et al., 1998]). Two periods of arc formation are distinguished: (1) an Eocene to Oligocene period 


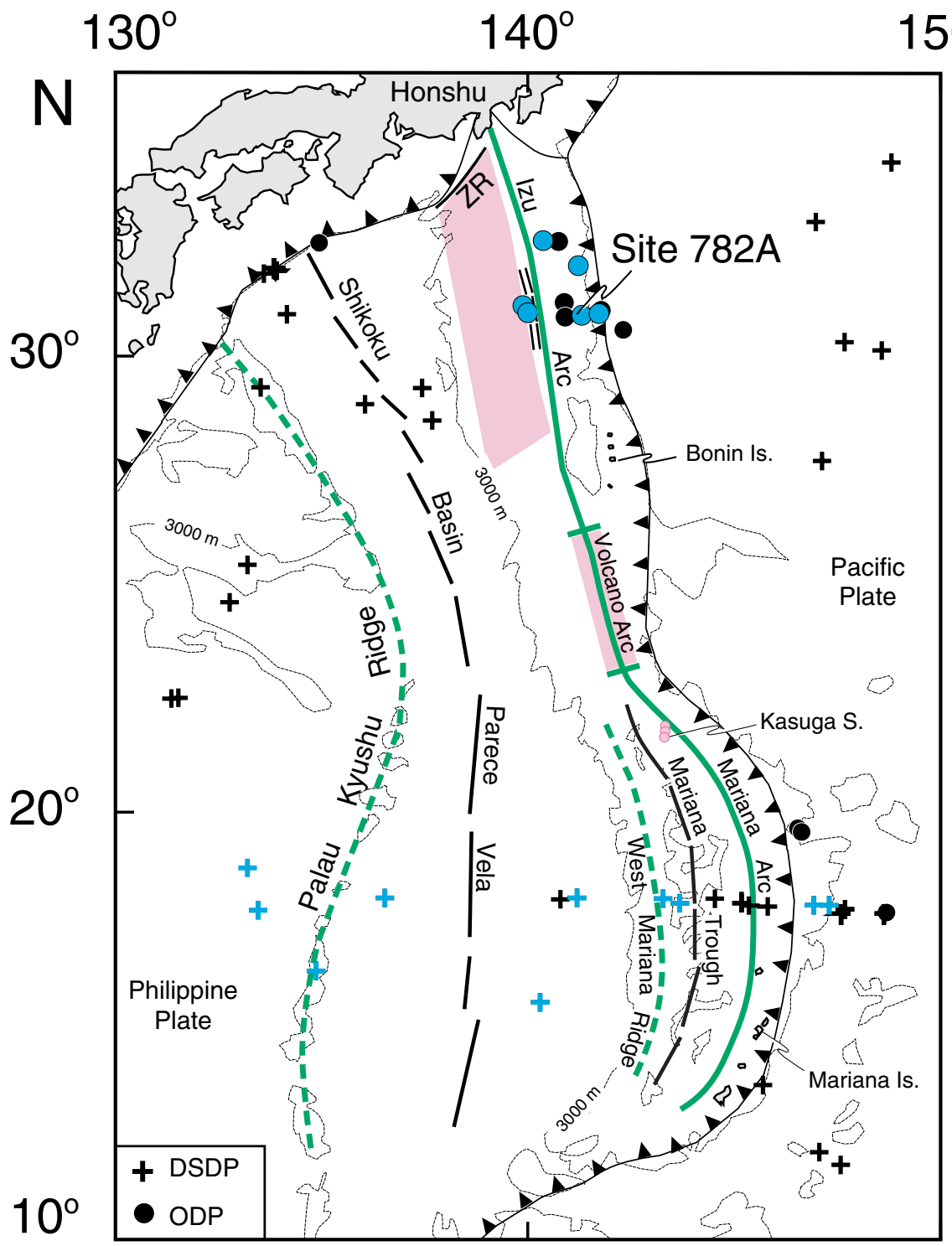

Figure 1. Regional geology of the Izu Bonin-Mariana arc/back arc system south of Japan. From East to West: Pacific Plate, Trench, Forearc, Volcanic Front (thick green solid line), rift (thick double line), rear arc, back arc basins (thick black solid lines) and remnant arcs (thick green stippled lines). ZR, Zenisu Ridge. Pink coloring shows the recorded occurrence of medium-K and high-K volcanic rocks in rear arc regions and at the interarc transition (Volcano arc). Filled circles are ODP drill sites, and crosses are DSDP drill sites. The sites from which fallout tephra was investigated are highlighted in blue.

(49-48 to $\sim 25 \mathrm{Ma}$ ), and (2) a Neogene period (since $\sim 20 \mathrm{Ma}$ ). These two periods are separated by a period of rifting (31-24 Ma) and backarc spreading (25-15 Ma) in the Shikoku and Parece Vela backarc basins. Since $6 \mathrm{Ma}$, a second cycle of arc splitting started that matured to backarc spreading in the Marianas. In the Izu Bonin arc, rifting has started at $\sim 2 \mathrm{Ma}$ immediately west to the volcanic front (Figure 1).
[6] The two periods of arc formation are structurally and chemically distinct. During the Eocene ( 48-38 Ma) the Izu Bonin and Mariana volcanic arcs formed a coherent terrane of $\sim 3000$ $\mathrm{km}$ length and $\sim 300 \mathrm{~km}$ width. The active volcanic zone probably narrowed in the late Eocene and early Oligocene, concurrent with the extension of the Izu Bonin forearc in the Oligocene [Taylor, 1992]. At the time of backarc 


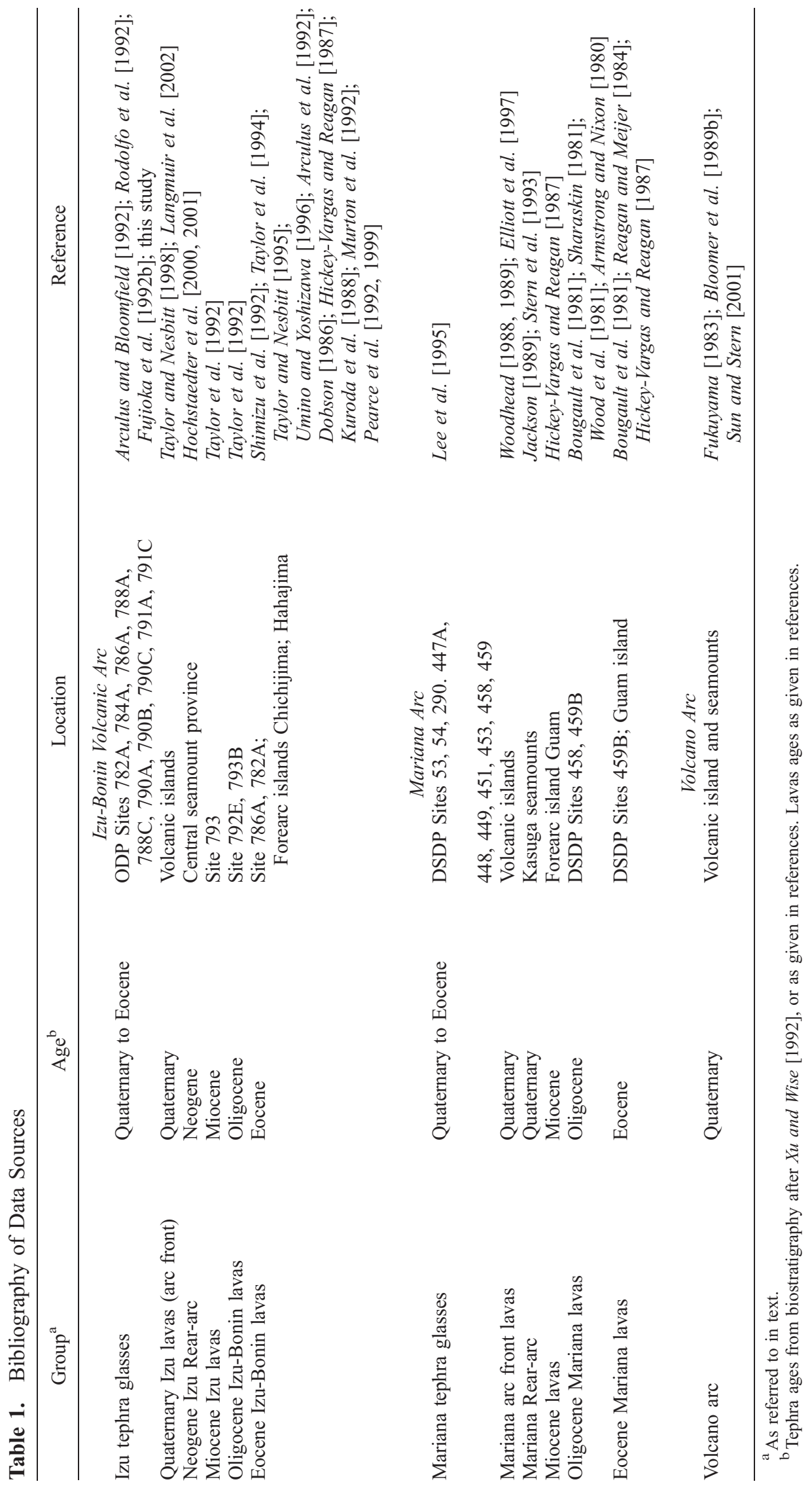


spreading, arc volcanicity in the Izu Bonin arc was at a minimum and may have even ceased [Taylor, 1992]. The post-backarc spreading history differs in the Izu Bonin and Mariana segments. In the Izu Bonin arc, a broad active zone of volcanism $(\sim 200 \mathrm{~km})$ persisted until the late Pliocene ( $\sim 3 \mathrm{Ma})$ [Hochstaedter et al., 2000]. Afterwards, the Izu Bonin reararc became inactive, except for the northernmost end at the Zenisu Ridge (ZR in Figure 1). The waning of volcanism is probably related to the incipient arc rifting at $\sim 2 \mathrm{Ma}$. The active volcanic zone of the Neogene Mariana arc is much narrower $(\sim 30$ $\mathrm{km})$ with a poorly developed volcanic reararc [Bloomer et al., 1989a]. A possible cause for the differing width of the volcanic zone may be the shallower angle of subduction in the Izu Bonin arc $\left(\sim 45-50^{\circ}\right)$ relative to the near-vertical angle $\left(\sim 89-90^{\circ}\right)$ beneath the central Marianas [van der Hilst et al., 1991; Plank and Kelley, 2001].

[7] Overall, the Izu Bonin and Mariana arc lavas display a considerable chemical diversity in time and space. In the Eocene and Oligocene, arc magmas are low-K tholeiites and boninites, that have the lowest contents of high-field-strength elements (HFSE) and rare earth elements (REE) of the magmas erupted throughout the arc history [Bloomer et al., 1995]. The Neogene period of arc formation is dominated by a broad spectrum of low-K, medium-K and subordinate shoshonitic compositions that are distributed in distinct spatial zones. Low-K tholeiitic magmas dominate the arc volcanic front, except for the transition between the Izu Bonin and Mariana arc segments (24$26^{\circ} \mathrm{N}$, Volcano arc) where medium-K and shoshonitic magmas erupt [e.g., Sun and Stern, 2001] (Figure 1). Medium-K magmas are common in the reararcs regions of both arcs [Stern et al., 1993; Hochstaedter et al., 2000; Hochstaedter et al., 2001]. The $\mathrm{K}_{2} \mathrm{O}$ abundances also display temporal variations. In the Mariana arc, the $\mathrm{K}_{2} \mathrm{O}$ contents of the arc magmas has increased gradually since early Miocene, and reached a maximum in the mid-Miocene at $\sim 7-12 \mathrm{Ma}$ [Lee et al., 1995]. In contrast, the $\mathrm{K}_{2} \mathrm{O}$ contents of the Neogene Izu Bonin arc front magmas remain low through time [Straub, 1996; Bryant et al., 1999].

\section{Data Compilation}

\subsection{Data Sources}

[8] The Mariana tephra profile is exclusively based on the electron microprobe data of Lee et al. [1995] that were obtained from fallout tephra from DSDP drill holes (Figure 1). The tephra profile for the Izu Bonin arc was compiled from new and previously published electron microprobe data of the ODP Leg 125 and 126 sites [Arculus and Bloomfield, 1992; Rodolfo et al., 1992; Fujioka et al., 1992b]. The new Izu Bonin glass data are all from fallout tephra drilled at ODP Site 782A that is located on the outer Izu Bonin forearc high (Figure 1). Site $782 \mathrm{~A}$ was chosen for detailed sampling because of the abundance of fallout tephra $(\sim 150$ discrete layers), the lack of substantiative re-deposition of the sediment, and the excellent biostratigraphic datability of the host sediment (nannofossil chalk). The age range is from Pleistocene to middle Eocene (44.4-47 Ma) [Xu and Wise, 1992]. The Neogene sequence is considerably thicker $(330 \mathrm{~m})$ than the Eocene and Oligocene sequence $(70 \mathrm{~m})$. A major hiatus of $7.5 \mathrm{Ma}$ between the upper Oligocene and middle Miocene [Xu and Wise, 1992] coincides with the temporary waning of Izu Bonin arc front volcanism. The numerical ages for the Izu Bonin tephra were either taken from the literature, or interpolated based on the sediment thickness and the biostratigraphic and paleomagnetic ages given in the Initial Reports [Fryer et al., 1990; Taylor et al., 1990]. The numerical ages for the Mariana tephra were taken from Lee et al. [1995]. The chemical data of the IBM lavas were compiled from the literature (see Table 1 for references). The Neogene IBM lavas have been sampled from the volcanic islands, or were dredged from the seamounts. These samples are mostly typical low-K and medium-K island arc tholeiites. Calc-alkaline rocks are rare. The Eocene and Oligocene IBM lavas were either drilled on the remnant Palau-Kyushu-Ridge, or on the forearc region east to the present volcanic front, or sampled from the forearc islands that 
Table 2. Repeatability of Electron Microprobe Analyses of Standards and Refererence Samples ${ }^{\mathrm{a}}$

\begin{tabular}{|c|c|c|c|c|c|c|c|c|c|}
\hline & \multicolumn{3}{|c|}{ JDF-D2 $(\mathrm{n}=77)$} & \multicolumn{3}{|c|}{ CFA $47(n=120)$} & \multicolumn{3}{|c|}{ ALV 981(n-101) } \\
\hline & ref. value & this study & $\mathrm{s} \%$ & ref. value & this study & $\mathrm{s} \%$ & ref. value & this study & $\mathrm{s} \%$ \\
\hline $\mathrm{SiO}_{2}$ & 50.80 & 50.20 & 1.5 & 61.63 & 61.78 & 1.4 & 49.53 & 49.14 & 1.5 \\
\hline $\mathrm{TiO}_{2}$ & 1.93 & 1.88 & 5.2 & 0.42 & 0.43 & 14 & 1.27 & 1.25 & 5.3 \\
\hline $\mathrm{Al}_{2} \mathrm{O}_{3}$ & 13.8 & 13.7 & 1.4 & 18.53 & 18.68 & 1.4 & 16.58 & 16.48 & 1.2 \\
\hline $\mathrm{FeO}^{*}$ & 12.17 & 12.06 & 3.7 & 2.65 & 2.82 & 6.1 & 8.42 & 8.73 & 3.7 \\
\hline $\mathrm{MnO}$ & 0.22 & 0.21 & 29 & 0.18 & 0.18 & 34 & 0.14 & 0.16 & 30 \\
\hline $\mathrm{MgO}$ & 6.83 & 6.76 & 1.9 & 0.42 & 0.42 & 7.1 & 8.86 & 8.75 & 2.1 \\
\hline $\mathrm{CaO}$ & 10.8 & 10.6 & 2.2 & 1.84 & 1.84 & 4.8 & 11.81 & 11.78 & 2.6 \\
\hline $\mathrm{Na}_{2} \mathrm{O}$ & 2.77 & 2.85 & 3.1 & 5.37 & 5.45 & 2.5 & 2.88 & 2.87 & 4.9 \\
\hline $\mathrm{K}_{2} \mathrm{O}$ & 0.215 & 0.21 & 13 & 7.98 & 8.02 & 1.7 & 0.05 & 0.05 & 39 \\
\hline $\mathrm{P}_{2} \mathrm{O}_{5}$ & 0.230 & 0.25 & 23 & & 0.08 & 37 & 0.06 & 0.14 & 27 \\
\hline Total & 99.77 & 98.3 & & 99.71 & 100.3 & & 99.55 & 100.3 & \\
\hline
\end{tabular}

${ }^{\mathrm{a}}$ All data in wt\%. JDF-D2 is a natural basalt glass from the East Pacific Rise developed by C. H. Langmuir (Lamont). References values are from personal communication. CFA 47 is a trachytic obsidian from the Phlegrean Fields (Italy), and ALV 981 is a natural basalt glass from the East Pacific Rise, both developed by N. Metrich (Gif-sur-Yvette). Reference values are from Metrich and Clochiatti [1989]. $n$ is the number of analyses during the 11 months measurement period at the Geomar (from 28.12.93 to 21.11.94). Precision (s\%) is reported as the percentage of one standard deviation of $n$ repeat analyses of the three reference glasses.

are uplifted blocks of the volcanic basement (Bonin Islands, Southern Mariana Islands; Figure 1). The majority of the Eocene and Oligocene samples $(\sim 65 \%)$ are either boninites in sensu strictu, which have $\mathrm{mg} \#>0.6[\mathrm{mg} \#=$ molar ratio of $\mathrm{MgO} /(\mathrm{MgO}+\mathrm{FeO})]$ and $\mathrm{SiO}_{2}>53 \mathrm{wt} \%$ [Crawford et al., 1989], or have chemical affinities to boninites (= boninitic rocks). The remaining samples are low-K island arc tholeiites.

\subsection{Sample Preparation and Analyses}

[9] The Site 782A tephra samples were freezedried, stirred in an ultrasonic bath and wet-sieved through a $32 \mu \mathrm{m}$ polyester screen using de-mineralized water. Standard thin sections were prepared from the coarse fraction that is a mixture of glass shards, lithic particles and phenocrysts (mostly plagioclase and pyroxenes). Most of the fallout tephras contain glass shards. The glass shards range from vesicle-poor sideromelane shards, to crystal- and vesicle- bearing shards, and to pumiceous and frothy shards. In some layers, the only volcanic glass present are melt inclusions in plagioclase and pyroxene phenocrysts. In the Eocene and Oligocene tephras, fresh glass shards are comparatively rare and $80 \%$ of the glass data are from melt inclusions. Only glasses without any sign of birefringence under crossed polarizers were analyzed.
[10] Electron microprobe analyses of the glasses (glass shards, melt inclusions) from 53 tephra samples were performed with a Cameca SX-50 microprobe at the GEOMAR Research Center (Kiel, F.R.G.). The instrument has four wavelength-dispersive spectrometers and was setup with $15 \mathrm{KeV}$ acceleration voltage, a rastered $3 \times 4 \mu \mathrm{m}$ beam and $6 \mathrm{nA}$ sample current for all elements. The thin bubble walls of the pumiceous glasses and the small size of the melt inclusions required the narrow beam. Under these conditions, heat-induced sodium loss is largely avoided, except for some sodium loss of $\left(<0.5 \mathrm{wt} \mathrm{Na}_{2} \mathrm{O} \%\right)$ in hydrous, high silica glasses $\left(>70 \mathrm{wt} \% \mathrm{SiO}_{2}\right)$. Natural and synthetic glasses and minerals were used for calibration. The precision and the accuracy were monitored by repetitive measurements of two basaltic glasses (JDF-D2 and ALV 981) and a trachytic glass (CFA-67) (Table 2). Typical precisions are (given as percentage of one standard deviation): $\mathrm{SiO}_{2}(1.4 \%), \mathrm{TiO}_{2}(8.0 \%), \mathrm{Al}_{2} \mathrm{O}_{3}$ (1.3\%), $\mathrm{FeO}^{*}$ (4.5\%), $\mathrm{MnO}$ (31\%), $\mathrm{MgO}(3.7 \%)$, $\mathrm{CaO}(3.2 \%), \mathrm{Na}_{2} \mathrm{O}(3.5 \%), \mathrm{K}_{2} \mathrm{O}(18 \%), \mathrm{P}_{2} \mathrm{O}_{5}$ (29\%). All new Izu Bonin glass data are listed in the auxiliary material (see http://www.agu.org).

\subsection{Data Correction}

[11] The best way to investigate the time-dependent trends of the major element oxides is to plot 


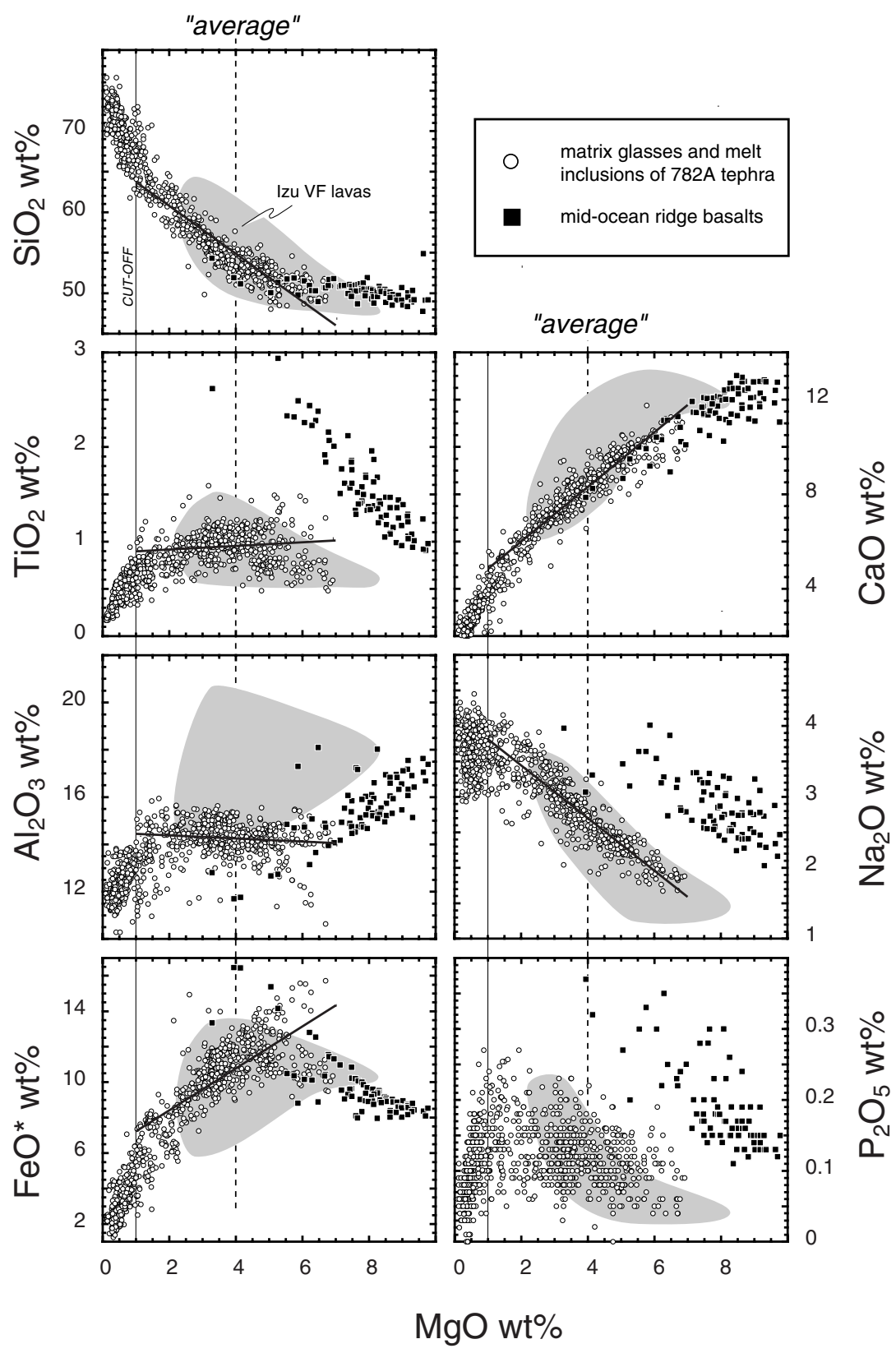

Figure 2. Abundances of major element oxides of Izu Bonin glasses (matrix glasses and melt inclusions) compared to Quaternary Izu Bonin arc front volcanic rocks and mid-ocean ridge basalts (MORB). Also shown is the "cut-off" at $1 \mathrm{wt} \% \mathrm{MgO}$ below which glasses were excluded from the data correction (see text). The "average" at $4 \mathrm{wt} \% \mathrm{MgO}$ indicates the value to which the data were corrected based on a linear regression (thick black line) trough all glasses with $\mathrm{MgO}>1 \mathrm{wt} \%$. Data sources are given in Table 1 .

their abundances against time. In practice, however, this method is difficult, owing to the broad compositional range of these elements in the high$\mathrm{MgO}$ basalts to rhyolites. One way to cope with this problem is to focus either on high-MgO samples $(>5 \mathrm{wt} \%)$, or on a narrow range of $\mathrm{MgO}$ values (e.g., $3-5 \mathrm{wt} \% \mathrm{MgO}$ ), assuming that the selected data contained all relevant petrogenetic information. However, either filter would exclude at least $2 / 3$ of the tephra glasses. This would severely detoriate the temporal resolution, next to biasing the data interpretation toward this group. In order to preserve the maximum amount of information as well as the temporal resolution, I choose 
Table 3. Equations Used to Correct Abundance of all IBM Tephra Glasses

\begin{tabular}{cl}
\hline Element oxides & \multicolumn{1}{c}{ Equations $^{\mathrm{a}}$} \\
\hline $\mathrm{SiO}_{2}$ & $\mathrm{SiO}_{2}=-2.974 * \mathrm{MgO}+66.688$ \\
$\mathrm{TiO}_{2}$ & $\mathrm{TiO}_{2}=0.0191 * \mathrm{MgO}+0.8783$ \\
$\mathrm{Al}_{2} \mathrm{O}_{3}$ & $\mathrm{Al}_{2} \mathrm{O}_{3}=-0.0659 * \mathrm{MgO}+14.508$ \\
$\mathrm{FeO}$ & $\mathrm{FeO}=1.1847 * \mathrm{MgO}+6.0488$ \\
$\mathrm{CaO}$ & $\mathrm{CaO}=1.1546 * \mathrm{MgO}+3.6904$ \\
$\mathrm{Na}_{2} \mathrm{O}$ & $\mathrm{Na}_{2} \mathrm{O}=-0.3711 * \mathrm{MgO}+4.1858$ \\
$\mathrm{~K}_{2} \mathrm{O}$ & $\mathrm{K}_{2} \mathrm{O}=-0.091691 * \mathrm{MgO}+0.56606$ \\
Dividing line & $\mathrm{K}_{2} \mathrm{O}=-0.1964 * \mathrm{MgO}+1.5441$ \\
\hline
\end{tabular}

\footnotetext{
${ }^{\mathrm{a}}$ The equations (except for $\mathrm{K}_{2} \mathrm{O}$ ) are linear regressions of the IzuBonin fallout tephra glasses with $\mathrm{MgO}<1 \mathrm{wt} \%$. The equation for $\mathrm{K}_{2} \mathrm{O}$ is a regression of the low-K glasses of Izu Bonin fallot tephra 125782A-11X-3-0-1.

${ }^{\mathrm{b}}$ The line separating Izu-Bonin fallout tephra into a low-K and a high-K group (line was fit manually).
}

to correct the individual analyses to a single $\mathrm{MgO}$ value of $4 \mathrm{wt} \% \mathrm{MgO}$, in a fashion similar to the approach of Plank and Langmuir [1988]. The choice of the low $\mathrm{MgO}=4 \mathrm{wt} \%$ was guided by the fact, that this value is close to arithmetic mean of the uncorrected abundance data of the tephra glasses and Quaternary IBM arc front lavas (Figure 2). Next to the advantage of focussing on the observed data, this also ensures a minimal error of the correction for these two data groups. All glasses were used to correct the $\mathrm{K}_{2} \mathrm{O}$ abundances, since $\mathrm{K}_{2} \mathrm{O}$ is an incompatible element in the IBM magmas. Figure 2 shows that the other major elements oxides of the Izu tephra and Quaternary Izu lavas glasses form broad bands when plotted against $\mathrm{MgO}$, and if glasses $<1 \mathrm{wt} \% \mathrm{MgO}$ are excluded that appear to represent strongly fractionated liquids (similar trends show from the Mariana glasses and Quaternary Mariana lavas [e.g., Lee et al., 1995; Straub, 1995]). Therefore, IBM glasses and lavas with $\mathrm{MgO}<1 \mathrm{wt} \%$ were excluded from the correction.

[12] The algorithms for correcting all major elements oxides of the Izu tephra glasses except $\mathrm{K}_{2} \mathrm{O}$ were obtained from linear regressions trough all glasses with $\mathrm{MgO}<1 \mathrm{wt} \%$ (Figure 2; Table 3). The algorithm for the $\mathrm{K}_{2} \mathrm{O}$ correction was obtained from a single, zoned tephra layer of very low $\mathrm{K}_{2} \mathrm{O}$ abundances (layer 19; Site 782A; Table 3). This was done in order to avoid negative values of corrected $\mathrm{K}_{2} \mathrm{O}$ abundance data. As result of this, the corrected medium- $\mathrm{K}$ glasses may be overesti- mated by as much as $0.5 \mathrm{wt} \% \mathrm{~K}_{4.0}$, but this amount is negligible for the overall result for this study. The algorithms derived from the Izu Bonin glasses were also used to correct the Mariana tephra glasses. The recalculated major oxides at $4 \mathrm{wt} \%$ $\mathrm{MgO}$ are indicated by the '4.0' subscript (e.g., $\mathrm{K}_{4.0}$ ). The MORB (mid-ocean ridge basalts) and the IBM lavas were also corrected to $\mathrm{MgO}=4$ $\mathrm{wt} \%$. For each group of IBM lavas (as listed in Table 1) and the MORB data, an individual set of regressions was used. The data set of Niu and Batiza [1997] was taken to represent global MORB because the very large number of major element analyses available for MORB renders the usage of the entire data set inconvenient.

\subsection{Benefits and Limits of the Data Correction}

[13] Given the wide range of rock types (glasses versus bulk rocks) and composition (basalt to rhyolites) compared at a single, low $\mathrm{MgO}$ content, it is advisable to consider the benefits and limitations of the data correction in more detail. Clearly, at a $\mathrm{MgO}=4 \mathrm{wt} \%$, the correction does not retrieve the temporal trends of primitive arc magmas. Rather, the correction delineates an 'arc bulk flux'. In theory, to obtain this 'arc bulk flux', it would be sufficient to plot the uncorrected abundance data. However, the correction procedure improves the comparability of the wide range of basalts to rhyolite, and aids as such in carving out time-dependent variations that might be lost in the scatter of the uncorrected abundance data. An assumption inherent to employing an 'arc bulk flux' is that the entire magma spectrum is ultimatively derived from the mantle. This does not exclude that a new batch of mantle magma may assimilate some material from the upper crust provided that (1) the crust assimilated has been formed by earlier magmas from the same sources [e.g., Tamura and Tatsumi, 2002]; and (2) the volume added from crust is small relative to the juvenile material from the mantle. This way, time-dependent evolutionary trends of individual elements should become visible. Even if this reasoning was speculative at first, it appears to be justified by the results that show significant 


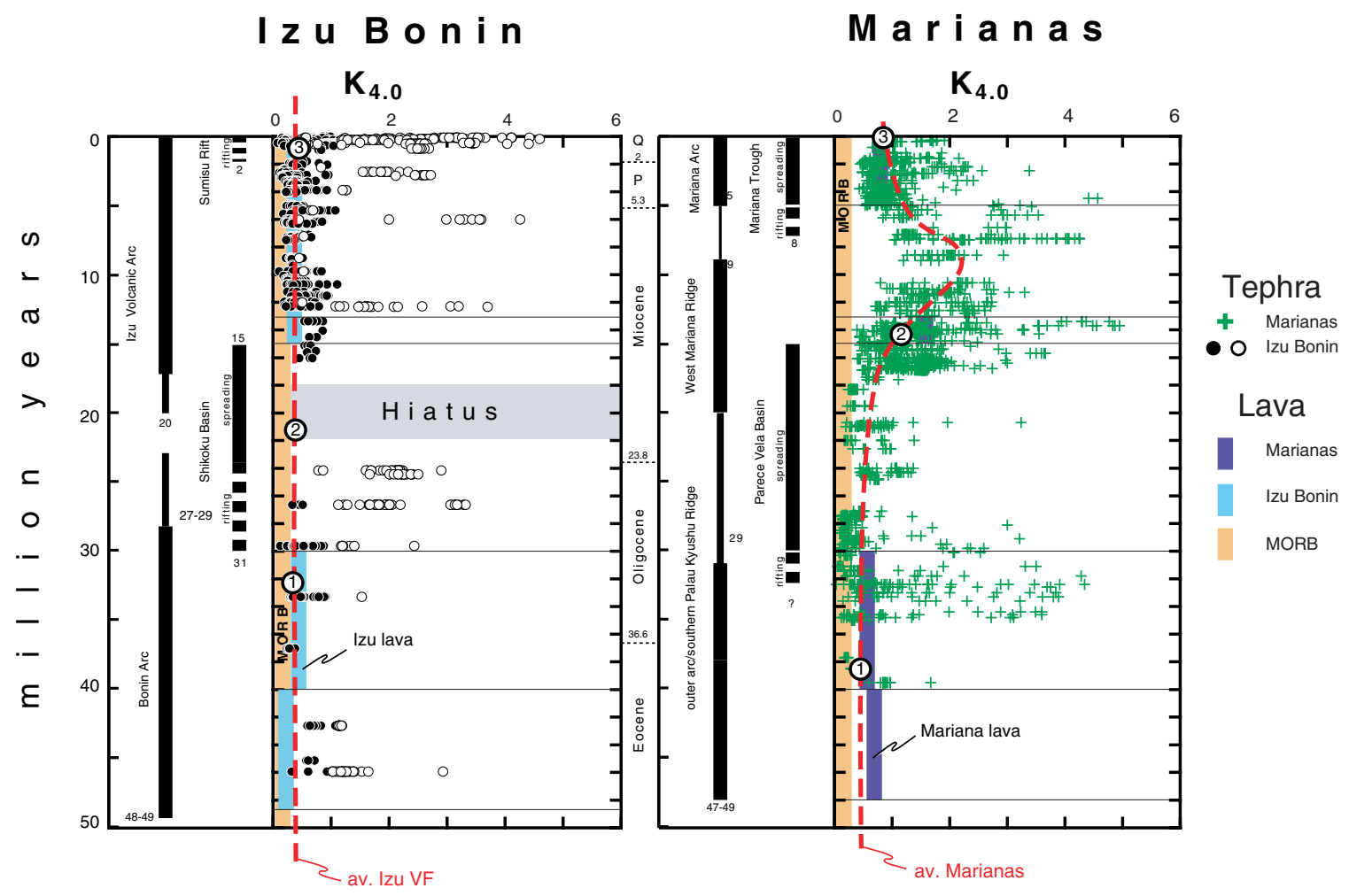

Figure 3. $\mathrm{K}_{4.0}$ trends of the Izu Bonin and Mariana arc. Data sources are given in Table 1. Fat blue vertical lines correspond to the average of Izu and Mariana lavas for a given interval of time. Hand-fitted stippled red lines are the presumed average trends of the arc volcanic front. Circled numbers (1 to 3) refer to Figures 18 and 19. Arc evolution after Taylor [1992] and Arculus et al. [1995]. See Table 1 for data sources.

temporal trends of the corrected major element oxides (e.g., $\mathrm{Na}_{4.0}$, or $\mathrm{K}_{4.0}$, or $\mathrm{Ti}_{4.0}$; Figures 3-8).

[14] The time-dependent trends of the corrected data exhibit considerable variations at a given age (Figures 3-8). Obviously, the data correction is inadequate as to smoothing out the variability induced by the processes that created the broad spectrum of basaltic to rhyolitic compositions in the first place (e.g., fractional crystallization, melt mixing, crustal assimilation). However, these processes are not the object of this paper, that instead focusses on the causes and significance of the timedependent trends of the 'arc bulk flux'. (Note a more detailed discussion of the processes of melt differentiation, including a discussion of the Tamura and Tatsumi [2002] model with respect to the Site 782A tephra data will be given in S. M. Straub et al. (The recycling of fluids and sediment melts in volcanic arcs, manuscript submitted to Geochemistry, Geophysics, Geosystems, 2002).
Because there are several ways to generate magmas with a low $\mathrm{MgO}$ of $4 \mathrm{wt} \%$, it must be asked which kind of information is contained in the trends of the corrected data. Do they reflect only the effects crustal differentiation, or is there still source significance? To this purpose, it was essential to support the data evaluation by examining (1) the uncorrected abundance data, and (2) the available trace element and isotope data. The outcome of the procedure is examplified by comparing lavas and tephra data from the Izu Bonin arc to MORB (Figure 2). Comprehensive trace element and isotope studies demonstrated that the Neogene Izu tephra glasses and the Quaternary Izu lavas are derived from the same magma sources [e.g., Schmidt, 2001; Straub et al., 2002]. However, the corrected and uncorrected abundance data of these two groups differ, presumable because phenocrystbearing magmas (= Izu VF lavas) are compared to fractionated melts (= glasses). The fractionation of plagioclase - that is abundant in the tephra - readily 

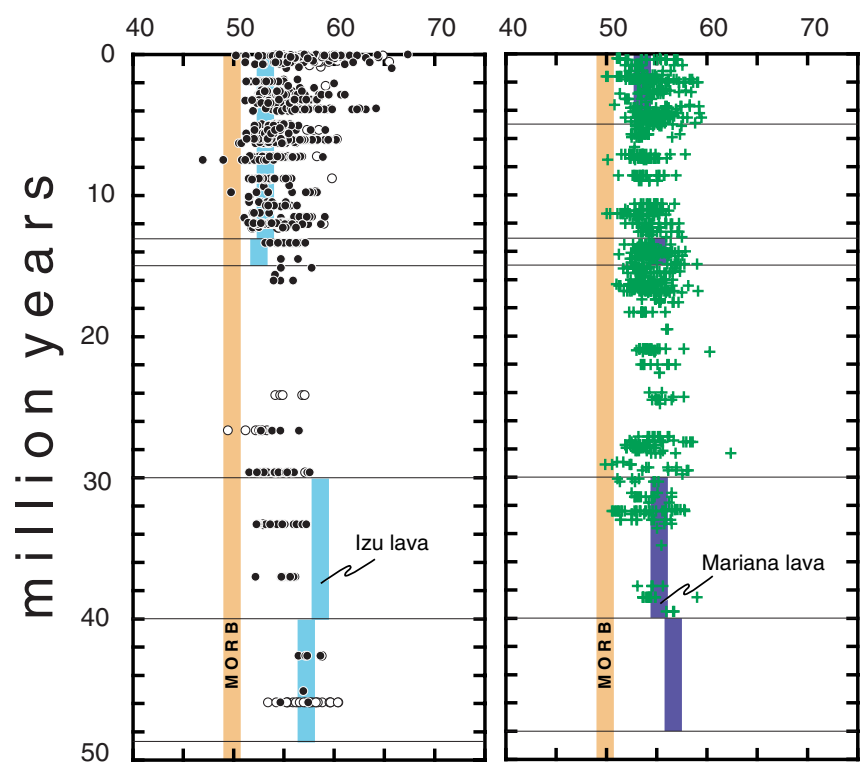

$\mathrm{Si}_{4.0}$

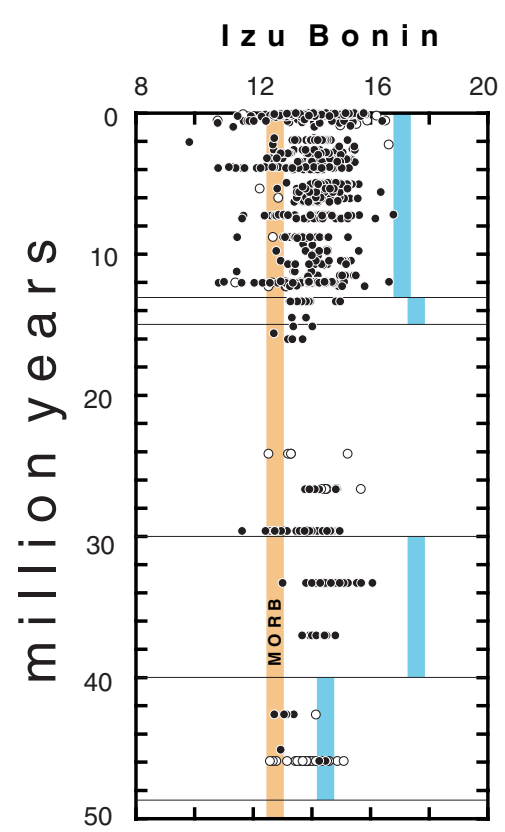

M a r i a n a s

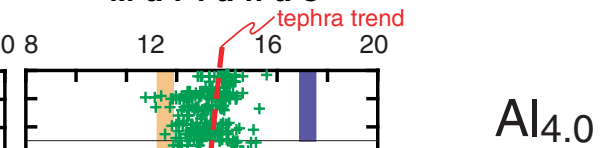

$\mathrm{Al}_{4.0}$

Figure 4. $\mathrm{Si}_{4.0}$ and $\mathrm{Al}_{4.0}$ trends of the Izu Bonin and Mariana arc. See Figure 3 for symbols and Table 1 for data sources.

accounts for the lower average $\mathrm{Al}_{2} \mathrm{O}_{3}$ and $\mathrm{CaO}$ of the glasses relative to the lavas. Further, the loss of plagioclase and pyroxene from melt might increase the $\mathrm{FeO} * \mathrm{MgO}$ ratios of the residual liquid. This could shift the composition of the glasses into the tholeiitic field in the $\mathrm{SiO}_{2}$ versus $\mathrm{FeO} * \mathrm{MgO}$ diagram [e.g., Straub, 1995], whereas the IBM lavas plot in both the tholeiitic and calc-alkaline fields [e.g., Tamura and Tatsumi, 2002]. On the other hand, Figure 2 also shows that, even despite these within-series disparities, some fundamental differences relative to MORB are not eradicated at $4 \mathrm{wt} \% \mathrm{MgO}$. MORB are more MgO-rich, and differ from the IBM magmas clearly in trace element and isotope chemistry [e.g., Taylor and Nesbitt, 1998]. In some elements (e.g., $\mathrm{CaO}, \mathrm{FeO}, \mathrm{SiO}_{2}$ ), the IBM magmas and MORB overlap. However, the oxides $\mathrm{Na}_{2} \mathrm{O}, \mathrm{TiO}_{2}$ and $\mathrm{P}_{2} \mathrm{O}_{5}$ that are characteristically low in the magmas from oceanic arcs [e.g., McCulloch and Gamble, 1991; Woodhead et al., 1993; Lang- 


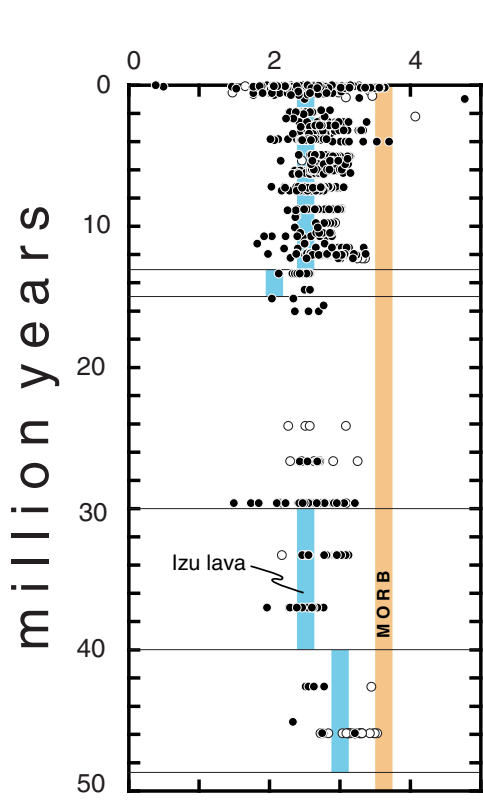

I z u B o n i n

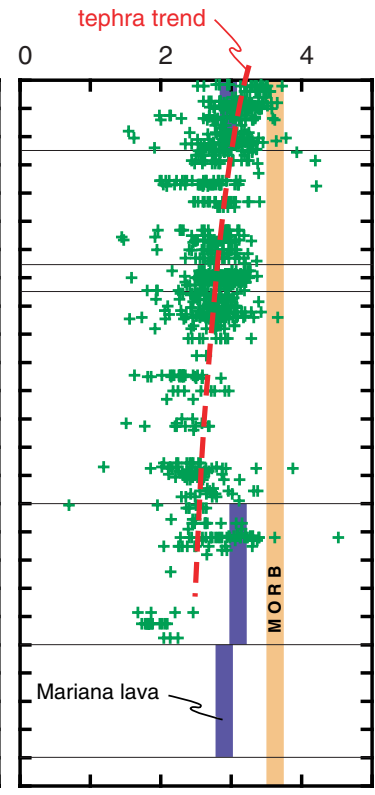

M a ri a n a s
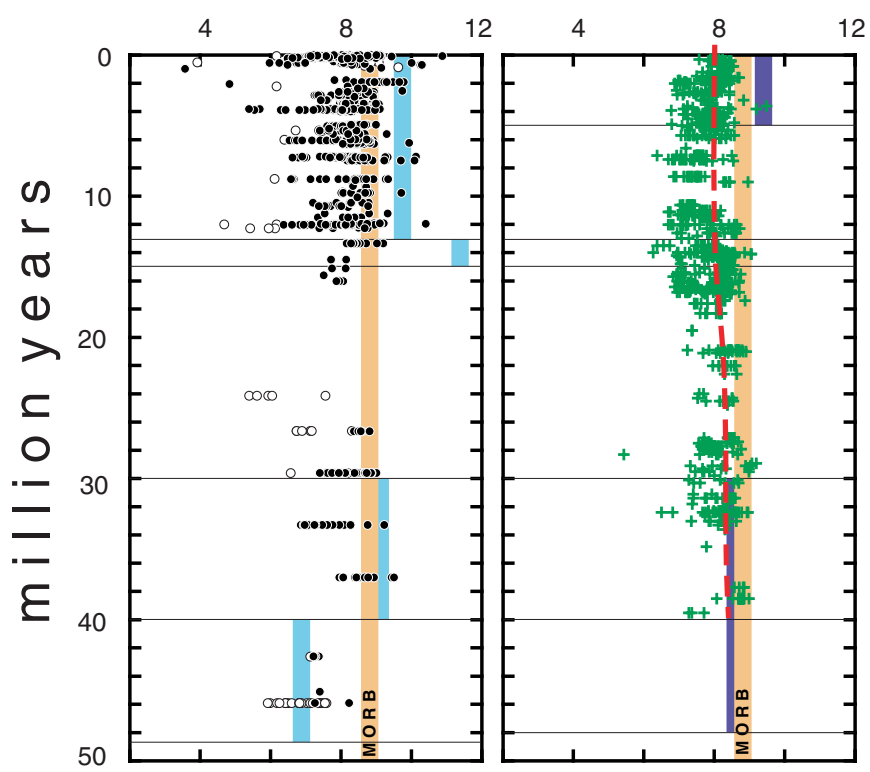

$\mathrm{Na}_{4.0}$

$\mathrm{Ca}_{4.0}$

Figure 5. $\mathrm{Ca}_{4.0}$ and $\mathrm{Na}_{4.0}$ trends of the Izu Bonin and Mariana arc. See Figure 3 for symbols and Table 1 for data sources.

muir et al., 2002], are always lower in the Izu Bonin tephra and lavas relative to the trends of MORB at any given $\mathrm{MgO}$. These disparities must be inherited from source, since no early crystallizing phases can deplete these elements from the Izu Bonin melts (e.g., Langmuir et al., 2002; Straub, manuscript in preparation, 2003). Therefore, disparities in the corrected abundances of these oxides must have have source significance. Similar evaluation proce- dures as given in this example were followed for all groups, and, if necessary, are discussed in more detail in the text.

\section{Results}

[15] The time-dependent trends of the corrected major element oxides are displayed in Figures 38. Each point (filled and open circles for Izu Bonin, 

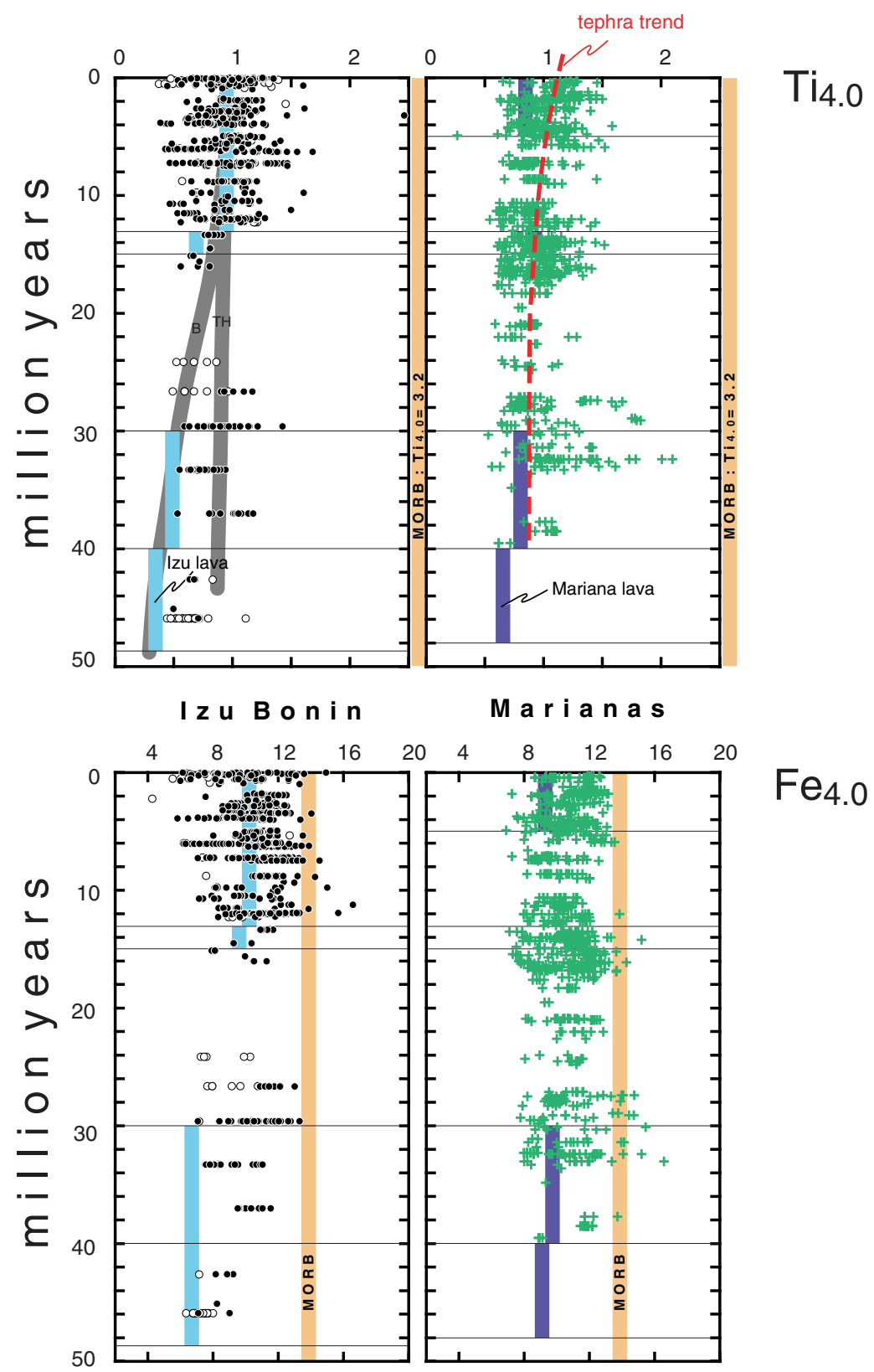

$\mathrm{Fe}_{4.0}$

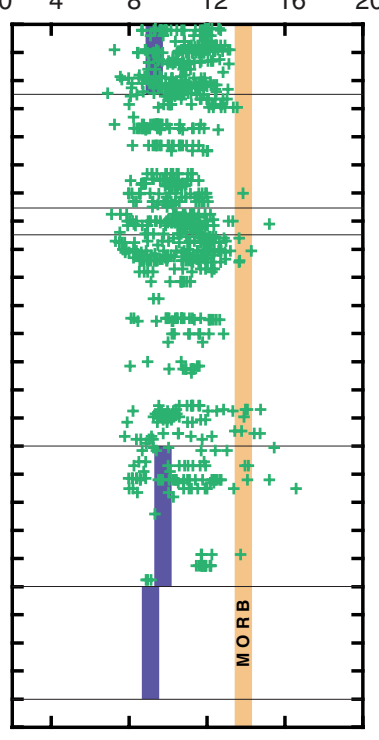

Figure 6. $\mathrm{Fe}_{4.0}$ and $\mathrm{Ti}_{4.0}$ trends of the Izu Bonin and Mariana arc. Hand-fitted grey lines indicate boninitic (B) and tholeiitic (TH) trends, respectively. See Figure 3 for symbols and Table 1 for data sources.

crosses for Marianas) represents a single glass shard or melt inclusion from tephra. Filled circles are the low-K glasses from the Izu Bonin arc, and open circles are the medium-K glasses. The average compositions of the IBM lavas for a given time interval are given by vertical bars, because the numerical ages of the individual lava samples are mostly not known. The limits of these time intervals are based on the published age data (from references in Table 1). The average of MORB is indicated by a vertical bar (brown). The red stippled lines, or grey solid lines are hand-drawn, and highlight temporal trends discussed in the text.

\subsection{Trends of $K_{4.0}$}

[16] The temporal trends of $\mathrm{K}_{4.0}$ reproduce several key characteristics of the IBM magmas that have been reported in previous studies [e.g., Arculus and 


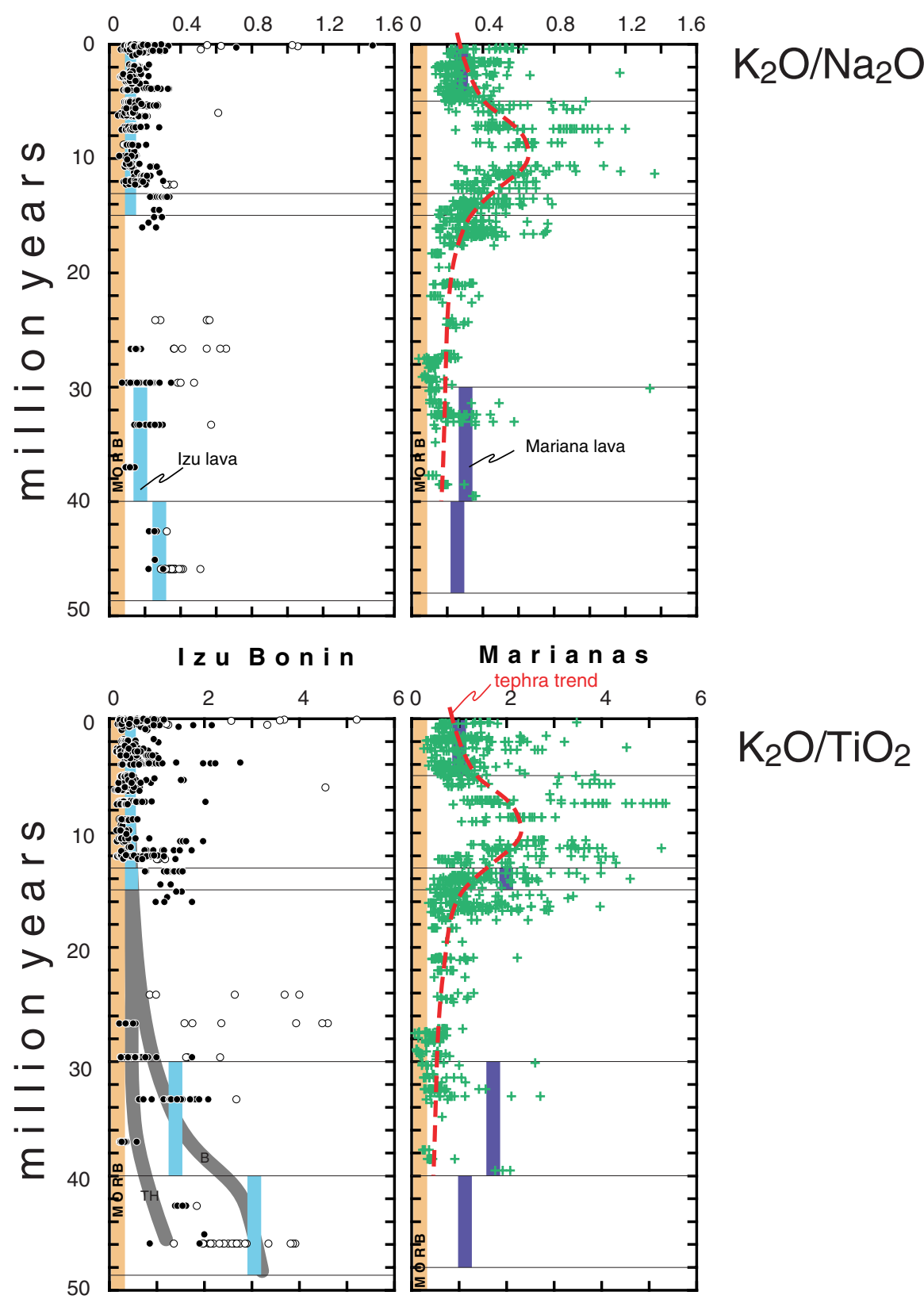

Figure 7. $\mathrm{K}_{2} \mathrm{O} / \mathrm{Na}_{2} \mathrm{O}$ and $\mathrm{K}_{2} \mathrm{O} / \mathrm{TiO}_{2}$ trends of the Izu Bonin and Mariana arc. Hand-fitted grey lines indicate boninitic (B) and tholeiitic (TH) trends, respectively. Note that the $\mathrm{K}_{2} \mathrm{O} / \mathrm{TiO}_{2}$ increase the Neogene Mariana tephra and the Eocene and Oligocene IBM lavas, respectively, have different causes. See Figure 3 for symbols and Table 1 for data sources.

Bloomfield, 1992; Lee et al. 1995; Bryant et al., 1999]. These are (1) the general increase of $K_{4.0}$ with time in the Mariana magmas, that reaches a temporary maximum at $\sim 7-12 \mathrm{Ma}$, and (2) the lower minimum $\mathrm{K}_{4.0}$ contents of the Izu Bonin magmas that show no fluctuations with time (Figure 3). Additional differences between the Izu
Bonin and Mariana arcs emerge when the frequency distribution of the uncorrected $\mathrm{K}_{2} \mathrm{O}$ abundances of the tephra glasses is considered (Figure 9). Both arcs have a similar broad range in $\mathrm{K}_{2} \mathrm{O}$ abundances from $\sim 0.1$ to $\sim 5 \mathrm{wt} \% \mathrm{~K}_{2} \mathrm{O}$. The Mariana glasses reach a frequency maximum at $\sim 1.2 \mathrm{wt} \% \mathrm{~K}_{2} \mathrm{O}$, whereby the abundance of 



\section{$\mathrm{Na}_{2} \mathrm{O} / \mathrm{TiO}_{2}$}

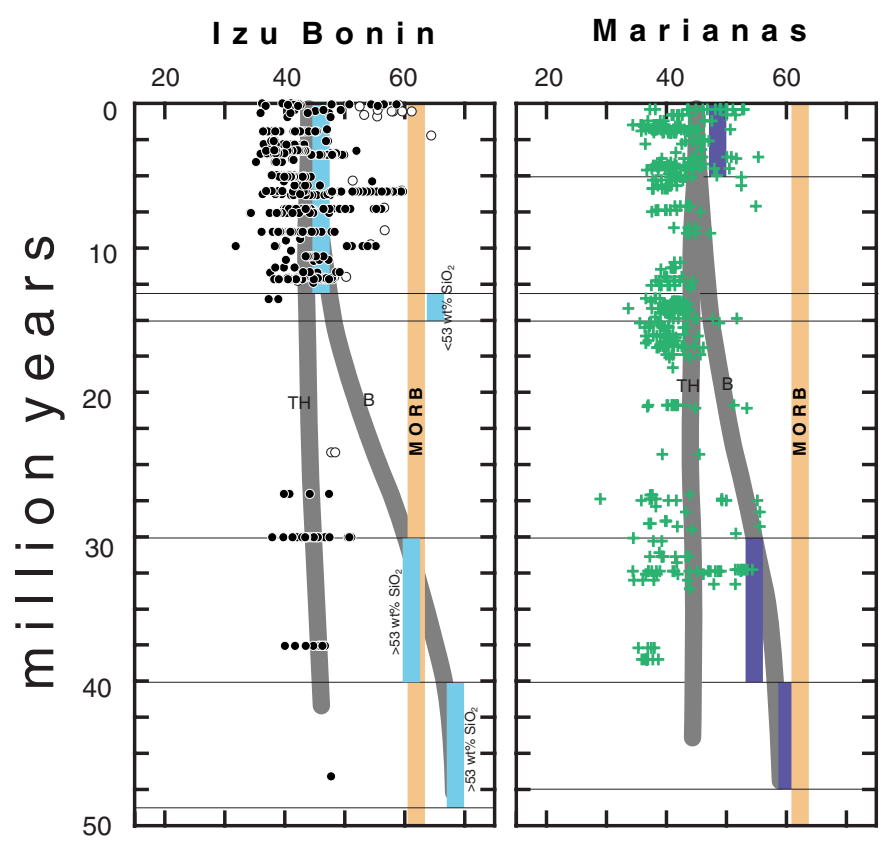

mg\#

Figure 8. $\mathrm{Na}_{2} \mathrm{O} / \mathrm{TiO}_{2}$ and $\mathrm{mg} \#$ trends of the Izu Bonin and Mariana arc. Only glasses $>3 \mathrm{wt} \% \mathrm{MgO}$ were use to calculate mg\# numbers. Hand-fitted grey lines indicate boninitic (B) and tholeiitic (TH) trends, respectively. See Figure 3 for symbols and Table 1 for data sources.

the individual glasses decreases rather smoothly with increasing $\mathrm{K}_{2} \mathrm{O}$ content (Figure 9b). By contrast, $\sim 80 \%$ of the Izu Bonin glasses cluster at $\sim 0.5$ wt $\% \mathrm{~K}_{2} \mathrm{O}$, with the abundances of the $\mathrm{K}_{2} \mathrm{O}$ richer glasses decreasing more rapidely with increasing $\mathrm{K}_{2} \mathrm{O}$ content than in the Mariana glasses (Figure 9a). At $\sim 2.5$ to $3 \mathrm{wt} \% \mathrm{~K}_{2} \mathrm{O}$ another, diffuse maximum appears to exist, indicating a slight bimodality in the overall distribution of the Izu Bonin glasses. In the $\mathrm{K}_{2} \mathrm{O}$ vs. $\mathrm{MgO}$ diagram (Figure 10), the low-K Izu Bonin glasses form a coherent group, in which the $\mathrm{K}_{2} \mathrm{O}$ contents increase by a factor of $\sim 3$ from basalt to rhyolite. By contrast, the medium- $\mathrm{K}$ glasses are exclusively dacitic to rhyolitic. The medium-K glasses of Site $782 \mathrm{~A}$, that are also distinctive by the presence of 


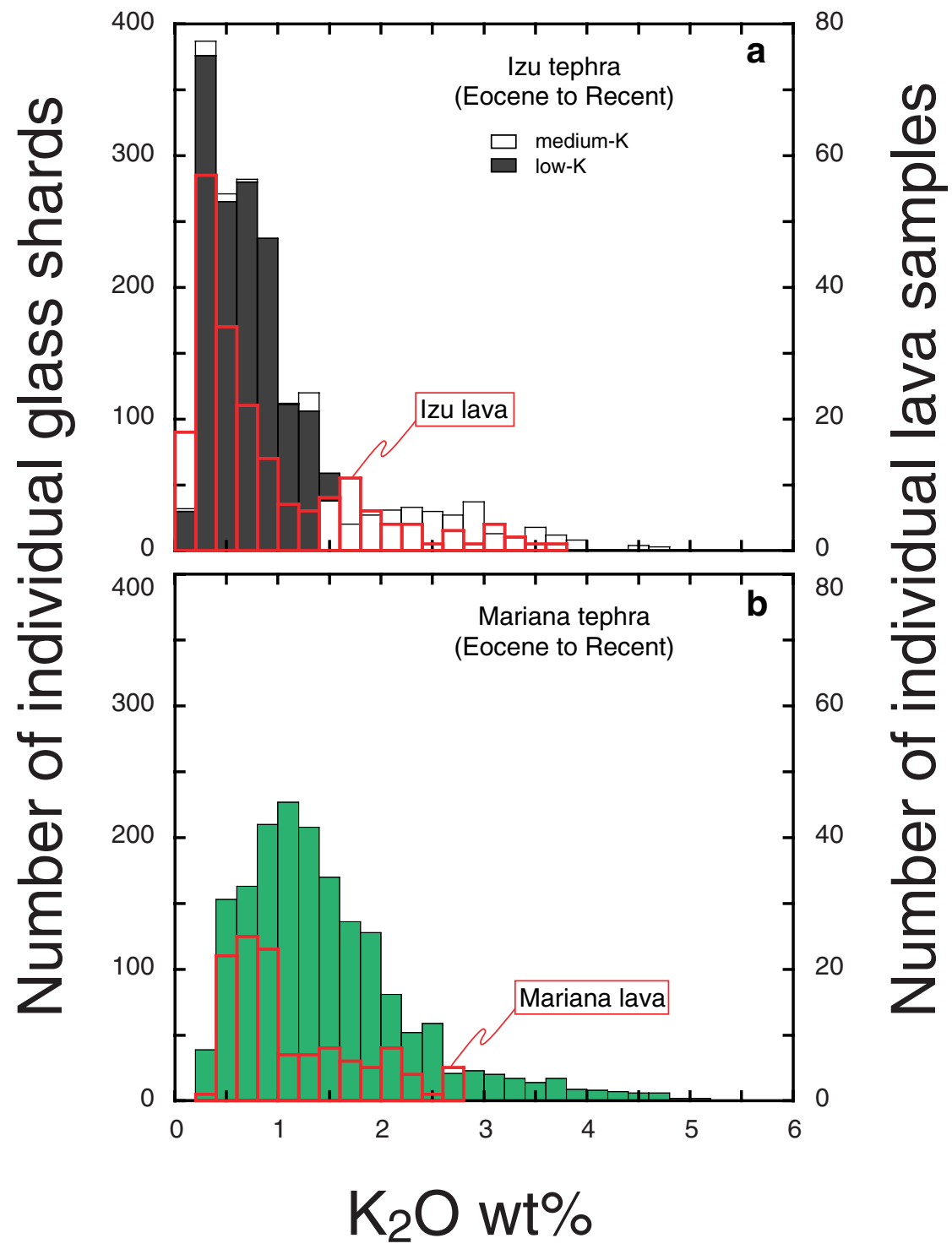

Figure 9. $\mathrm{K}_{2} \mathrm{O}$ histograms for (a) Izu Bonin and (b) Mariana tephras (Eocene to Recent) compared to the Neogene IBM lavas (red outline). Data sources as in Table 1. For subdivision of Izu Bonin tephra into low-K and medium compositions see text.

amphibole, can be separated from the low-K glasses of the same site by a hand-fitted line of the equation $\mathrm{K}_{2} \mathrm{O}=-0.1964 \mathrm{MgO} \mathrm{wt} \%+1.5441$. This equation was then used to distinguish low-K and medium-K glasses in all Izu Bonin glasses.

[17] The $\mathrm{K}_{2} \mathrm{O}$ characteristics of the IBM glasses are reminiscent of those of the Neogene Izu Bonin and
Mariana arc lavas. As the tephra glasses, the Mariana arc lavas form a rather coherent group, in which the $\mathrm{K}_{2} \mathrm{O}$ content gradually increases from the arc front to the reararc region. In contrast, the Neogene Izu lavas reach a frequency maximum at lower $\mathrm{K}_{2} \mathrm{O}$ values, and show a broader distribution with a second minor maximum at higher $\mathrm{K}_{2} \mathrm{O}$ contents (Figure 9). In the central Izu Bonin arc, 


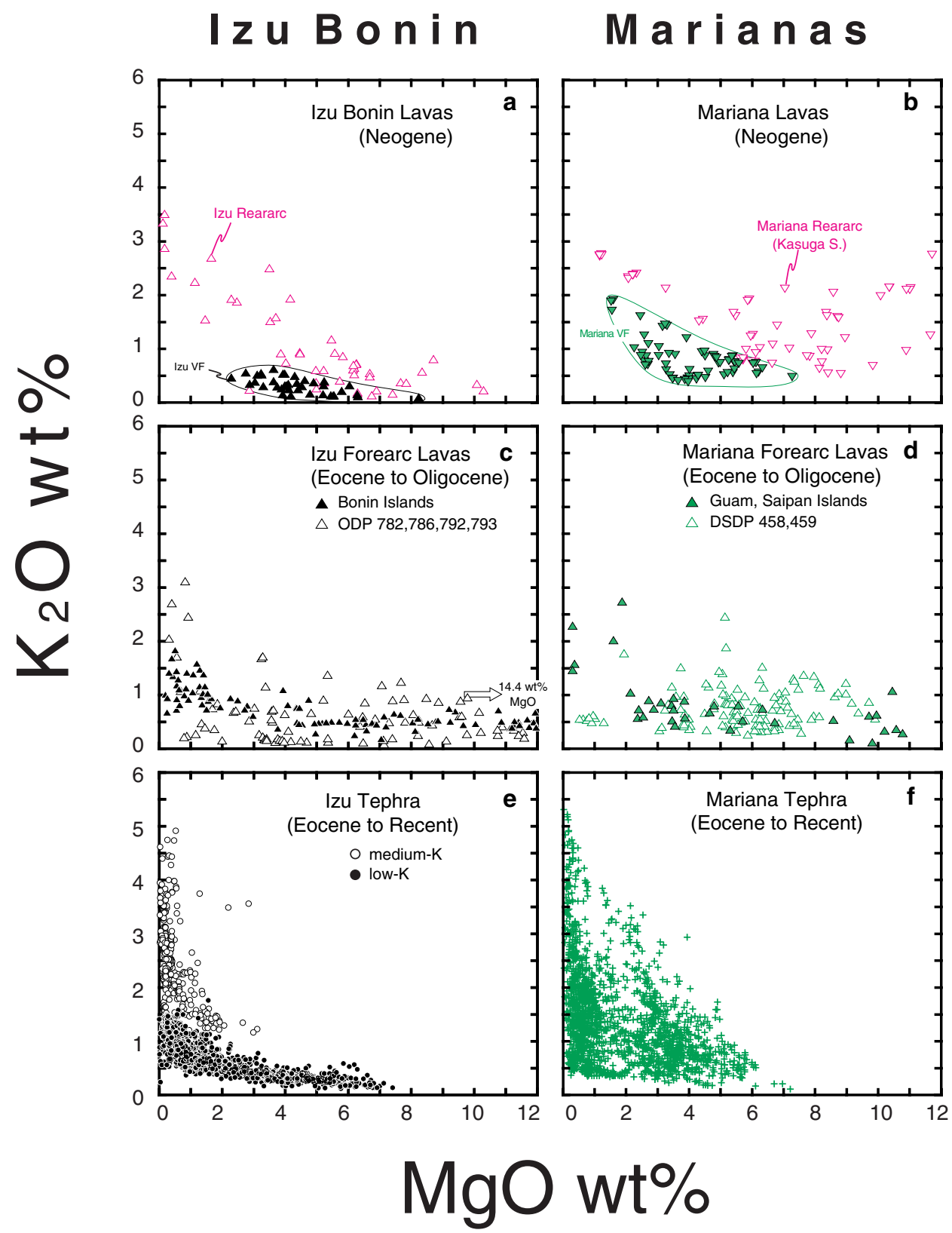

Figure 10. (a-f) $\mathrm{K}_{2} \mathrm{O}$ versus $\mathrm{MgO}$ for Izu Bonin (left panels) and Mariana (right panels) arc lavas and tephra. Data sources in Table 1.

the low-K arc magmas originate primarily from the arc volcanic front, whereas the medium-K lavas are confined to the reararc region. The available trace element and isotope analyses of the Izu Bonin tephra are consistent with an origin of low-K and medium-K glasses from Izu Bonin arc front and reararc, respectively [Bryant et al., 1999; Schmidt, 2001; Straub et al., 2002] (Table 4). The comparative rarity of the medium-K tephra in the ODP drill sites may indicate a lesser explosivity of the reararc volcanoes, but could also be an artefact of the proximity of the drill sites to the arc front, rather than to the reararc region.

\subsection{Trends of the Other Major Elements}

[18] In contrast to $\mathrm{K}_{4.0}$, the abundances and temporal trends of the "other major element oxides" 
Table 4. Bulk ICP-MS Analyses of an Miocene (layer 87) and Three Oligocene and Eocene Izu Tephra (Layers 106, $108,117)^{\mathrm{a}}$

\begin{tabular}{|c|c|c|c|c|c|c|}
\hline Sample No. & 29XCC-5-7 & $37 X-4-43-45$ & $39 X-1-21-23$ & $42 X-2-99-101$ & BHVO This work & BIR This work \\
\hline Code No. & 87 & 106 & 108 & 117 & & \\
\hline Age (Ma) & 12.31 & 26.64 & 29.61 & 45.12 & & \\
\hline $\mathrm{SiO}_{2}$ & 66.67 & 72.02 & 58.61 & 67.54 & & \\
\hline $\mathrm{TiO}_{2}$ & 0.33 & 0.14 & 0.81 & 0.43 & & \\
\hline $\mathrm{Al}_{2} \mathrm{O}_{3}$ & 14.05 & 11.90 & 13.85 & 12.50 & & \\
\hline $\mathrm{FeO}^{*}$ & 2.60 & 1.06 & 8.43 & 3.88 & & \\
\hline $\mathrm{MnO}$ & 0.16 & 0.08 & 0.19 & 0.11 & & \\
\hline $\mathrm{MgO}$ & 0.36 & 0.18 & 2.90 & 0.70 & & \\
\hline $\mathrm{CaO}$ & 1.77 & 1.46 & 6.70 & 3.28 & & \\
\hline $\mathrm{Na}_{2} \mathrm{O}$ & 4.21 & 2.88 & 2.93 & 3.26 & & \\
\hline $\mathrm{K}_{2} \mathrm{O}$ & 2.32 & 2.61 & 0.70 & 1.03 & & \\
\hline $\mathrm{P}_{2} \mathrm{O}_{5}$ & 0.07 & 0.04 & 0.14 & 0.11 & & \\
\hline Total & 92.81 & 92.53 & 95.48 & 93.00 & & \\
\hline $\mathrm{Sc}$ & 13 & 3 & 26 & 16 & 31.5 & 46.3 \\
\hline $\mathrm{Cr}$ & 8 & 8 & 9 & 7 & 309 & 406. \\
\hline Co & 2 & 3 & 19 & 13 & 47 & 58.2 \\
\hline $\mathrm{Ni}$ & 8 & 5 & 6 & 17 & 128 & 193 \\
\hline $\mathrm{Cu}$ & 8 & 7 & 102 & 39 & 146 & 132 \\
\hline $\mathrm{Zn}$ & 97 & 36 & 93 & 82 & 122 & 82 \\
\hline $\mathrm{Ga}$ & 17 & 11 & 13 & 12 & 21.4 & 16.0 \\
\hline $\mathrm{Cs}$ & 1.10 & 1.07 & 1.06 & 0.74 & 0.105 & 0.046 \\
\hline $\mathrm{Tl}$ & 0.27 & 0.22 & 0.12 & 0.13 & 0.043 & 0.005 \\
\hline $\mathrm{Pb}$ & 6.08 & 3.74 & 7.01 & 6.73 & 2.2 & 3.1 \\
\hline $\mathrm{Sr}$ & 156 & 172 & 183 & 113 & 380 & 110 \\
\hline $\mathrm{K}$ & 19231 & 2166 & 581 & 855 & & \\
\hline $\mathrm{Rb}$ & 35.0 & 34.5 & 11.7 & 17.5 & 9.37 & 0.270 \\
\hline $\mathrm{Ba}$ & 159.5 & 274.2 & 134.2 & 45.6 & 118 & 8 \\
\hline $\mathrm{Th}$ & 2.52 & 2.28 & 0.45 & 0.32 & 1.23 & 0.033 \\
\hline $\mathrm{U}$ & 0.86 & 0.80 & 0.24 & 0.24 & 0.418 & 0.014 \\
\hline $\mathrm{Nb}$ & 6.69 & 1.17 & 1.03 & 0.52 & 17.20 & 0.53 \\
\hline $\mathrm{Ta}$ & 0.48 & 0.11 & 0.06 & 0.03 & 1.14 & 0.040 \\
\hline $\mathrm{La}$ & 17.45 & 9.36 & 2.90 & 2.36 & 14.70 & 0.595 \\
\hline $\mathrm{Ce}$ & 42.06 & 19.29 & 7.73 & 5.91 & 36.40 & 1.87 \\
\hline $\mathrm{P}$ & 305 & 175 & 611 & 480 & & \\
\hline $\operatorname{Pr}$ & 6.06 & 2.38 & 1.27 & 0.98 & 5.22 & 0.373 \\
\hline $\mathrm{Nd}$ & 27.11 & 9.15 & 6.79 & 5.02 & 23.90 & 2.35 \\
\hline $\mathrm{Sm}$ & 7.16 & 1.84 & 2.36 & 1.64 & 6.01 & 1.10 \\
\hline $\mathrm{Zr}$ & 232 & 96 & 53 & 62 & 171 & 14.4 \\
\hline Hf & 6.14 & 2.86 & 1.81 & 2.01 & 4.34 & 0.596 \\
\hline $\mathrm{Eu}$ & 1.75 & 0.48 & 0.76 & 0.51 & 2.00 & 0.508 \\
\hline $\mathrm{Ti}$ & 1977 & 839 & 4853 & 2576 & & \\
\hline $\mathrm{Gd}$ & 7.65 & 1.77 & 3.15 & 2.06 & 6.13 & 1.74 \\
\hline $\mathrm{Tb}$ & 1.32 & 0.29 & 0.60 & 0.38 & 0.921 & 0.351 \\
\hline Dy & 8.61 & 1.84 & 4.11 & 2.55 & 5.200 & 2.520 \\
\hline $\mathrm{Li}$ & 5 & 4 & 10 & 21 & 4.63 & 3.53 \\
\hline $\mathrm{Y}$ & 55.0 & 13.3 & 26.3 & 16.4 & 26.8 & 16.20 \\
\hline Ho & 1.84 & 0.40 & 0.91 & 0.56 & 0.957 & 0.560 \\
\hline $\mathrm{Er}$ & 5.64 & 1.32 & 2.79 & 1.72 & 2.51 & 1.68 \\
\hline $\mathrm{Tm}$ & 0.84 & 0.22 & 0.41 & 0.26 & 0.322 & 0.254 \\
\hline $\mathrm{Yb}$ & 5.79 & 1.62 & 2.80 & 1.79 & 1.96 & 1.63 \\
\hline $\mathrm{Lu}$ & 0.89 & 0.28 & 0.43 & 0.28 & 0.270 & 0.240 \\
\hline
\end{tabular}

${ }^{\text {a }}$ Major elements are averages of individual glass shards and melt inclusions measured by electron microprobe. Ages after $X u$ and Wise [1992]. About 20-100 milligram of fresh glassy or lithic particles was handpicked from the fraction $>35 \mu m$ under a binocular microscope. The sample were stirred repeatedly in an ultrasonic bath, rinsed with de-mineralised water and crushed in an agate mortar. The powders were weighed into Teflon beakers and decomposed by a pressurized $\mathrm{HF}-\mathrm{HClO}_{4}$-aqua regia attack as described by Garbe-Schönberg [1993]. The analyses of 14 rare earth and 21 other trace elements were performed using a VG PlasmaQuad PQ 1 ICP mass spectrometer equipped with a multichannel analyser at the Geological Institute of the University of Kiel (analyst CD Garbe-Schönberg). Also given are concurrent analyses of international standards BIR and BVHO. Accuracy and precision of the mass spectrometer are better that $3 \%$ for the rare earth elements and better than $5 \%$ for most other trace elements. 


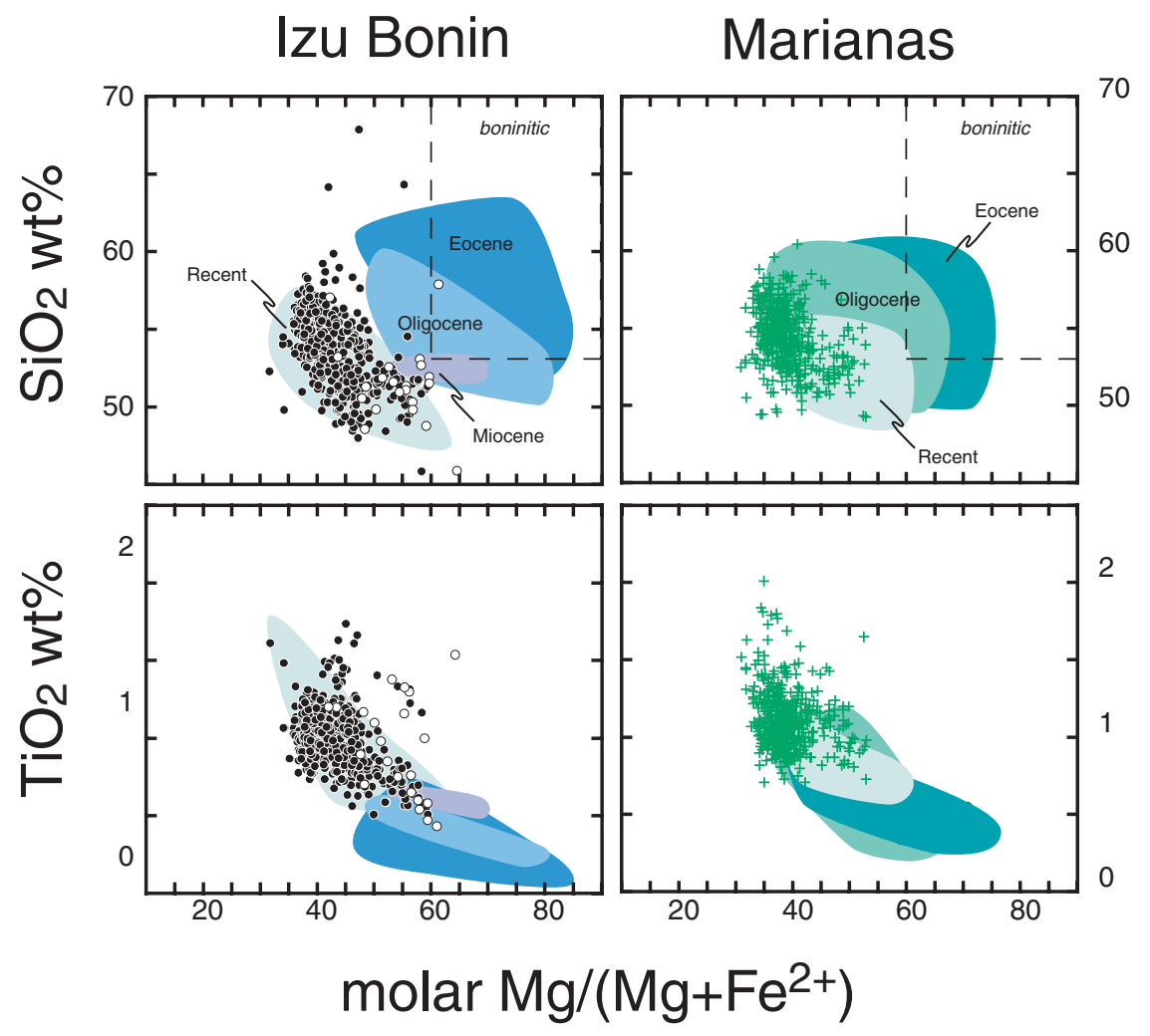

Figure 11. $\mathrm{SiO}_{2}$ and $\mathrm{TiO}_{2}$ versus $\mathrm{mg} \#$ for Izu Bonin and Mariana arcs. Tephra are given as circles (Izu Bonin) and crosses (Mariana). Lavas are given as fields. Boninitic compositions (mg\# $>60$ and $\mathrm{SiO}_{2}<53$ wt $\%$ ) defined after Crawford et al. [1989]. Note the gradual decrease in $\mathrm{mg \#}$ and $\mathrm{SiO}_{2}$, and increase in $\mathrm{TiO}_{2}$ of lavas with time, indicating to a general shift from boninitic to tholeiitic composition. The tephra glasses are always tholeiitic. Data sources as in Table 1.

$\left(\mathrm{Si}_{4.0}, \mathrm{Ti}_{4.0}, \mathrm{Al}_{4.0}, \mathrm{Fe}_{4.0}, \mathrm{Ca}_{4.0}\right.$ and $\left.\mathrm{Na}_{4.0}\right)$ are similar in the Izu Bonin and the Mariana arcs. The tephra trends show no drastic temporal variations (Figures 3-8). Only in the Mariana tephra glasses, some slight, but perceptible temporal trends emerge. The $\mathrm{Na}_{4.0}, \mathrm{Ti}_{4.0}$ and $\mathrm{Al}_{4.0}$ abundances of the tephra appear to increase slightly, but perceptibly with time. These increases appear to be paralleled by a very slight decrease in $\mathrm{Ca}_{4.0}$ (Figures 5 and 6). Further, the Neogene Mariana tephra glasses show tighter compositional trends of $\mathrm{Al}_{4.0}$, $\mathrm{Fe}_{4.0}, \mathrm{Ca}_{4.0}$ and $\mathrm{Ti}_{4.0}$ during the Neogene than Izu Bonin glasses (Figures 4-6).

[19] The IBM lavas do not always overlap with the the trends of the co-eval tephra glasses. In the Neogene, the discrepancies in the corrected abundances tephra glasses and lavas stem from comparing glasses to whole rock analyses (Figure 2; see above). However, the Eocene and Oligocene tephra and lavas of the Izu Bonin differ in some key elements and element ratios, that define the boninitic nature of the lavas. These are the lower $\mathrm{Ti}_{4.0}$ of the Eocene-Oligocene lavas, that are coupled with high $\mathrm{Si}_{4.0}$ abundances and high mg\# values. These characteristics are best visible in diagrams of the uncorrected abundance data that combined these three elements (Figure 11). In this diagram, the Eocene and to some extent the Oligocene IBM lavas overlap with the field of boninites (defined after Crawford et al., 1989). The tephra and lavas differ in particular by their $\mathrm{TiO}_{2}$ contents. Figure 12 shows that the $\mathrm{TiO}_{2}$ abundances of the IBM tephra and lavas range from $\sim 0.2$ to $\sim 1.4 \mathrm{wt} \%$ at low $\mathrm{MgO}$ values of $\sim 2-4 \mathrm{wt} \%$. The large range at a given $\mathrm{MgO}$ excludes fractional crystallization as cause for the $\mathrm{TiO}_{2}$ variability, which must then be inherited from source. Because of the very low 


\section{Izu Bonin}
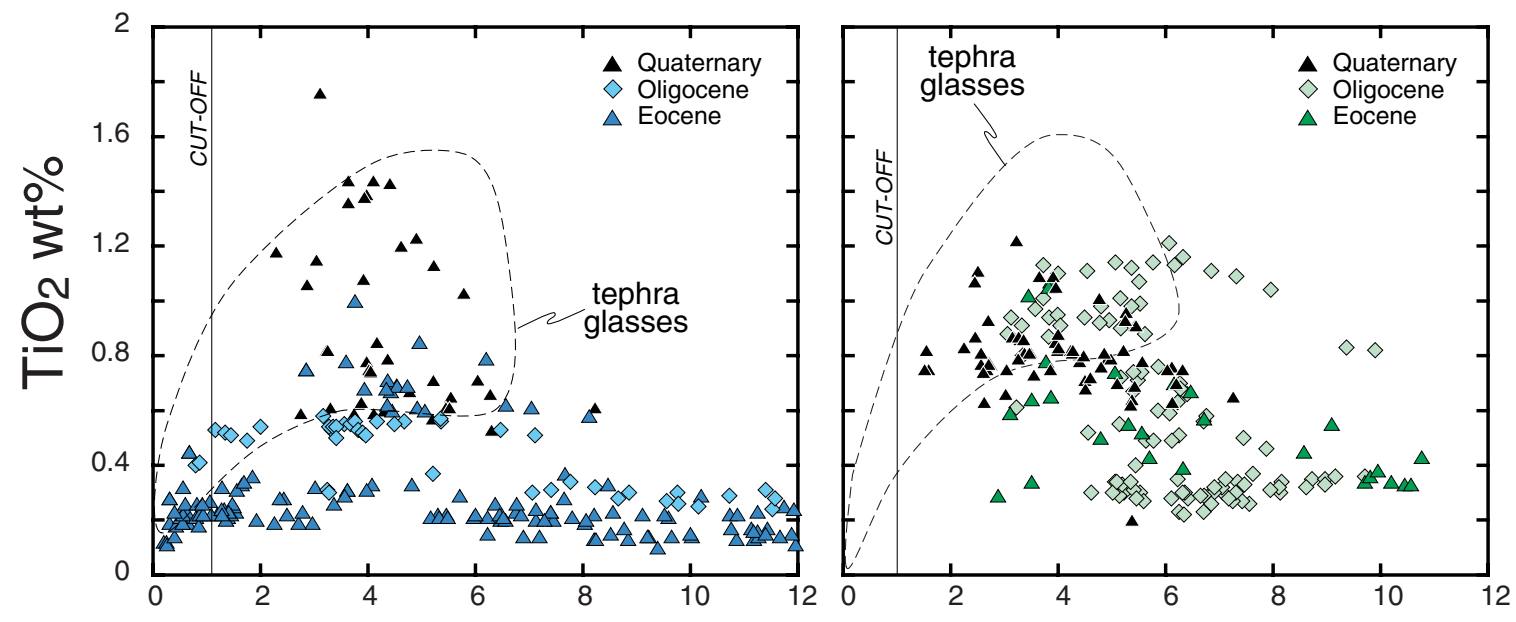

\section{$\mathrm{MgO}$ wt\%}

Figure 12. $\mathrm{TiO}_{2}$ versus $\mathrm{MgO}$ abundances of Izu Bonin and Mariana lava, illustrating the wide range in $\mathrm{TiO}_{2}$ content as well as the general increase of the $\mathrm{TiO}_{2}$ content in the lavas with time. Compositons $<1 \mathrm{wt} \% \mathrm{MgO}$ (vertical line labeled "cut-off") are not included in the corrected data in Figure 7. Note that the high-TiO $2(>0.4$ wt $\%)$ and low $\mathrm{TiO}_{2}(<0.4 \mathrm{wt} \%)$ samples are separated in the Eocene-Oligocene Izu Bonin arc, in contrast to the more continuous spectrum of the Mariana arc lavas. Data sources as in Table 1.

$\mathrm{TiO}_{2}$ abundances the Eocene and Oligocene Izu lavas (but not the tephras) have high $\mathrm{K}_{2} \mathrm{O} / \mathrm{TiO}_{2}$ and $\mathrm{Na}_{2} \mathrm{O} / \mathrm{TiO}_{2}$ ratios.

[20] It is striking that in terms of major elements, the Eocene-Oligocene tephras glasses are never boninitic, and always resemble the Neogene tholeiites. Lee et al. [1995] have noted this phenomenom for the Mariana tephra glasses, which is now shown to apply for Izu Bonin tephra glasses as well. However, the major element record is not entirely adequate. Figure $13 \mathrm{~b}$ shows that characteristic trace element signature of boninite magmas is apparent in a single high-silica rhyolitic tephra at 26.3 Ma (late Oligocene). The sample has very low REE abundances $(\sim 0.2-0.6$ times N-MORB; Table 4), but a high $(\mathrm{La} / \mathrm{Sm})_{\mathrm{n}}$ ratio $=3.3$, hence forming a pattern reminiscent of the typical Ushaped REE pattern of boninites. This tephra - and potentially other high-silica tephra with similar trace element patterns - are excluded from the major elements plots because of their low $\mathrm{MgO}$ content $<1 \mathrm{wt} \%$. The quartz-bearing dacite lavas of Chichijima Island [Umino, 1986] might be an extrusive counterpart of this tephra.

\section{Discussion}

[21] From the temporal trends of the IBM tephra glasses and lavas at least three features emerge that warrant further discussion. First, what are the causes of the $\mathrm{K}_{4.0}$ variability? Second, why do tholeiitic and boninitic magmas co-exist during the early arc evolution and why do the boninitic magmas disappear with time? Third, what is the significance of the relative temporal constancy of the other major element oxides exhibited by the tephra?

\subsection{Causes and Significance of the $K_{4.0}$ Variability}

[22] Various models have been proposed in order to explain the wide range in $\mathrm{K}_{2} \mathrm{O}$ abundances of the IBM magmas. Crustal differentiation, or a variable extent of melting of a homogeneous subarc mantle [e.g., Meijer and Reagan, 1983] as causes could unambiguously be excluded when comprehensive, high-quality data of trace elements and isotopes became available [e.g., Lin et al., 1989; Tatsumi et al., 1992; Stern et al., 1993]. The variations of $\mathrm{K}_{2} \mathrm{O}$ 
Izu Bonin

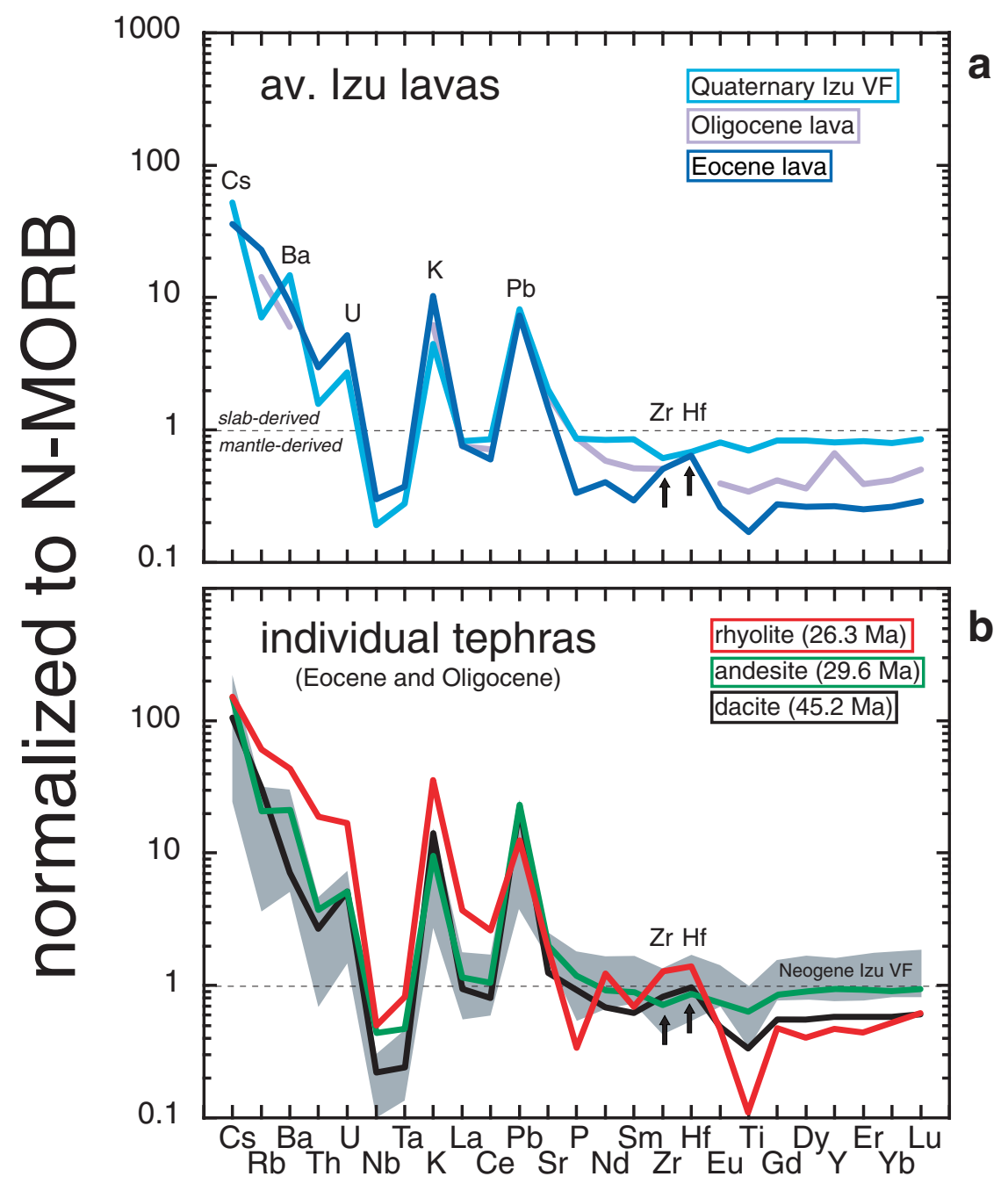

Figure 13. (a) Average abundances of incompatible trace elements in Eocene, Oligocene and Quaternary Izu Bonin lavas. Elements $<1$ relative to average the N MORB of Sun and McDonough [1989] originate largely from the wedge [Straub et al., 2002]. Note the very low REE abundances and the positive $\mathrm{Zr}$ and Hf anomalies of the Eocene lavas, and the intermediate abundances of the Oligocene lavas relative to the Quaternary lavas. Data sources in Table 1. (b) Three fallout tephras of Eocene and Oligocene age from Site 782A are compared to the range of the Neogene tephras (grey shaded field). Note the extreme HREE depletion and the positive $\mathrm{Zr}$ and Hf anomalies of the Oligocene rhyolitic tephra, that are coupled with high relative contents LREE. This results in an U-shaped REE pattern that is reminiscent of boninite magmas.

by a factor of 2 to 4 in high-MgO rocks were found to correlate with the changes in the ratios of radiogenic isotopes $(\mathrm{Sr}, \mathrm{Nd}, \mathrm{Pb})$, and of highly incompatible trace elements. This clearly indicates substantial heterogeneity of the subarc mantle sources [e.g., Lee et al., 1995; Elliott et al., 1997; Bryant et al., 1999; Hochstaedter et al., 2000; Hochstaedter et al., 2001; Sun and Stern, 2001]
(Figure 10). To date, the causes of this source heterogeneity are highly debated. Since the increase in $\mathrm{K}_{2} \mathrm{O}$ can be coupled to an increase in the abundances of incompatible elements that are poorly mobile in slab-derived fluids (e.g., HFSE, LREE), and to a decrease in $\mathrm{Nd}$ isotope ratios, several models proposed that the subarc mantle was interspersed with enriched, OIB-like domains 
[e.g., Lin et al., 1990; Stern et al., 1993; Hochstaedter et al., 2001; Sun and Stern, 2001]. However, regardless of the absolute enrichment and the variable isotopic composition, the IBM volcanics always exhibit an 'arc signature', i.e. have the typically high ratios of large-ion lithophile elements (LILE) relative to $\mathrm{Nb}$. Since HFSE and LREE are also transported in partial melts of the subducting sediment that is unradiogenic in $\mathrm{Nd}$ isotopes [e.g., Elliott et al., 1997; Johnson and Plank, 1999], the possibility exists that the enriched mantle domains formed by the selective infiltration of a sediment melt component, in addition to the ubiquitious slab fluid components. In this model, the background mantle (= metasomatized mantle wedge minus subduction component) is fairly depleted in highly incompatible elements, and any significant enrichment involving these elements is primarily caused by the additions of fluid and melt components from slab.

[23] It is noteworthy that the data compilation strongly favors the latter model, since this appears to be the only possibility to account for the contrasting behaviour of $\mathrm{Na}_{4.0}, \mathrm{Ti}_{4.0}$ and $\mathrm{K}_{4.0}$ in the Neogene Mariana arc at the low and constant values of $\mathrm{Ti}_{4.0}$ and $\mathrm{Na}_{4.0}$ (Figures 3, 5, and 6; $\mathrm{P}_{2} \mathrm{O}_{5}$ is not considered here). $\mathrm{K}_{2} \mathrm{O}, \mathrm{Na}_{2} \mathrm{O}$ and $\mathrm{TiO}_{2}$ all behave incompatibly during partial melting of a peridotite mantle, although the bulk D's of $\mathrm{Na}_{2} \mathrm{O}$ and $\mathrm{TiO}_{2}$ are higher ( 0.2 [Langmuir et al., 1992]) than those of $\mathrm{K}_{2} \mathrm{O}$ ( $\mathrm{D} \sim 0.01$ [Kelemen et al., 1993]). Moreover, $\mathrm{Na}_{2} \mathrm{O}$ and $\mathrm{TiO}_{2}$ are typically enriched in OIB-like mantle sources, that have abundances that are similar, or higher than average $\mathrm{N}$-MORB. Therefore, if the $\mathrm{K}_{4.0}$ increase by a factor of $\sim 3$ in the Neogene Mariana arc was due either to a lower extent of melting, or to the temporary involvement of an enriched mantle domain, then a concurrent increase in $\mathrm{Na}_{4.0}$ and $\mathrm{Ti}_{4.0}$ can be expected, even if the abundance of these elements increased less than $\mathrm{K}_{4.0}$. Quite on the contrary, the constancy of the $\mathrm{Na}_{4.0}$ and $\mathrm{Ti}_{4.0}$ trends during that period suggests that neither the extent of melting, nor the composition of the mantle wedge change significantly during the Neogene. Moreover, the low abundance of $\mathrm{Ti}_{4.0}$ and $\mathrm{Na}_{4.0}$ relative to MORB (that is also present in the uncorrected element abundances shown in Figure 2) are entirely consistent with the models, that propose the IBM arc front magmas to be generated by high extent of melting of $\sim 20-25 \%$ from a depleted MORB source mantle [Stolper and Newman, 1994; Elliott et al., 1997; Hochstaedter et al., 2000; Langmuir et al., 2002].

[24] If the IBM background mantle is at least as depleted as N-MORB, simple mass balance requires, that most of the $\mathrm{K}_{2} \mathrm{O}$ present at the arc front is derived from the slab $(>90 \%$ [Hochstaedter et al., 2001; Straub et al., 2002]. In the most simple slab input/arc output model, the arc outflux of $\mathrm{K}_{2} \mathrm{O}$ is a linear function of the slab influx, that is in turn a product of the convergence rate, the thickness and the $\mathrm{K}_{2} \mathrm{O}$ content of the slab [Plank, 1993; Plank and Langmuir, 1993]. However, the variations of these parameters cannot account for the temporary increase of $\mathrm{K}_{4.0}$ during the late Miocene. The absence of such a signal in the neighboring Izu Bonin arc, and the magnitude of the increase by about factor of $\sim 3$, precludes a variable convergence rate as cause. If the thickness or composition of the subducting slab was the cause, then the Mariana slab must have become increasingly thicker, or richer in $\mathrm{K}_{2} \mathrm{O}$ since the early Miocene, and it must have been exceptionally thick, or $\mathrm{K}_{2} \mathrm{O}$-rich, at $\sim 7-12 \mathrm{Ma}$. Possibly, this might reflect the subduction of an exceptionally thick $\mathrm{K}_{2} \mathrm{O}$-rich crust, that is covered by up to 1000 $\mathrm{m}$ thick volcaniclastic aprons, or that is interspersed with alkaline lavas from the Cretaceous intraplate seamounts. However, why should the subduction of a seamount province have a temporary effect only, as seamount subduction is apparently a re-occuring event, that still persists today? These inconsistencies strongly indicate that there is an additional factor, that controls the amount of $\mathrm{K}_{2} \mathrm{O}$ released from slab.

[25] In the light of the recycling models recently discussed, this factor may be the differing transport capacity of fluids and melts [e.g., Elliott et al., 1997; Plank and Kelley, 2001; Straub et al., 2002]. The slab component beneath the Neogene Izu arc front, that has the typical characterisitics of a fluid, contains $\sim 1$ to $2 \mathrm{wt} \% \mathrm{~K}_{2} \mathrm{O}$ [Hochstaedter et al., 2001; Straub et al., 2002]. If an equivalent fraction 


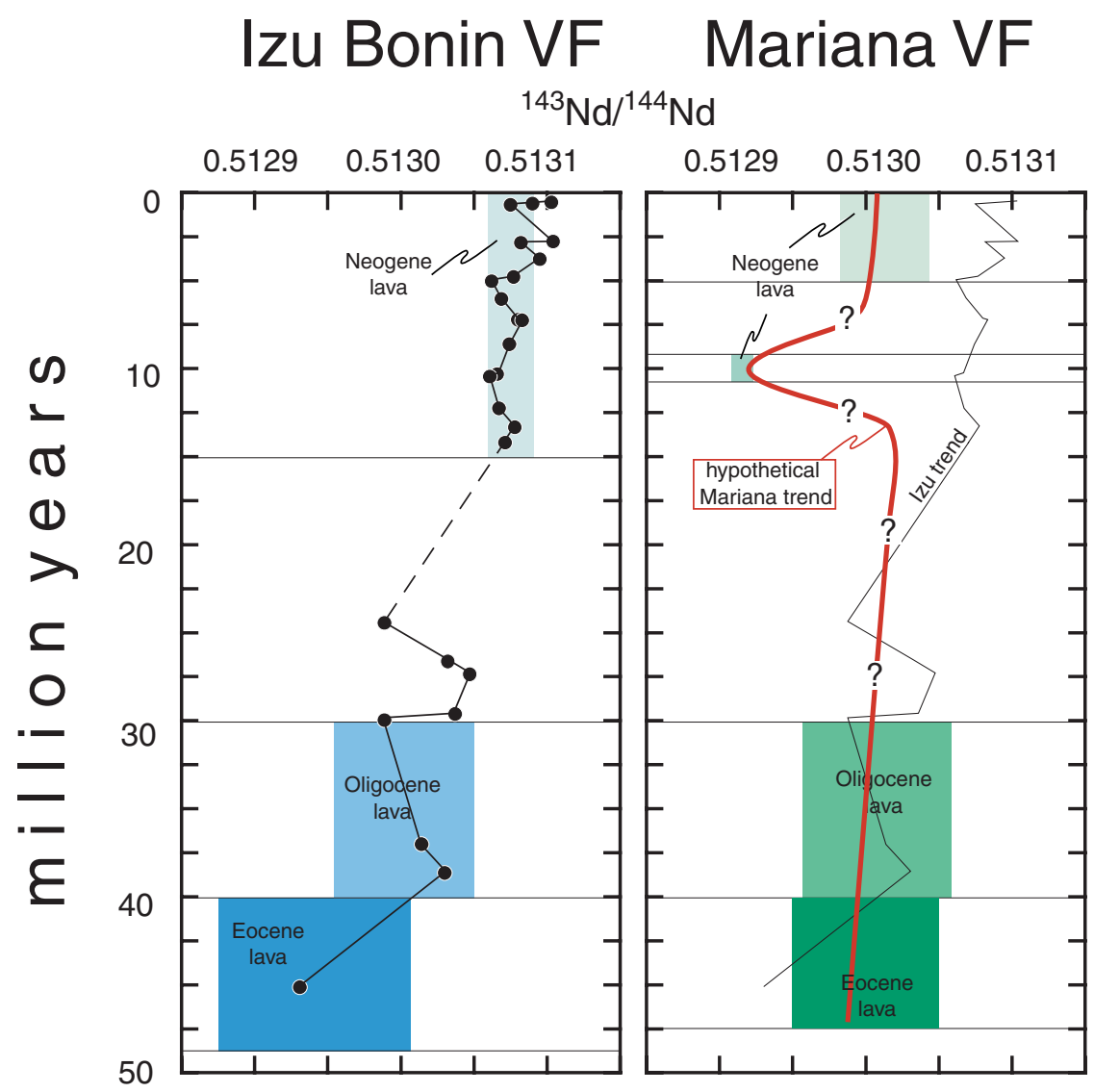

Figure 14. ${ }^{143} \mathrm{Nd} /{ }^{144} \mathrm{Nd}$ trends of Izu Bonin and Mariana arc front volcanics. Data sources as in Table 1, except for ${ }^{143} \mathrm{Nd} /{ }^{144} \mathrm{Nd}$ data of the Izu Bonin tephra that are from Schmidt [2001]. The decreasing trend at the Izu Bonin VF is interpreted to reflect the evolution of the subarc mantle wedge. The Neogene Mariana VF would probably follow a comparable trend, if the Neogene arc had not been refertilized by unradiogenic Nd transported in slab derived sediment melts. The sediment melt flux is particular high in the mid-Miocene [Bryant et al., 1999]. Unfortunately, the $\mathrm{Nd}$ isotope record of the Neogene Mariana arc is incomplete, and only a hypothetical Nd isotope trend can be drawn (red line with question marks) that is based on the few existing data (mid-Miocene and Quaternary lavas; see Table 1 for data sources).

of sediment melt in source had a much higher $\mathrm{K}_{2} \mathrm{O}$ and LILE abundances (e.g., as much as $\sim 2-5.5$ $\mathrm{wt} \% \mathrm{~K}_{2} \mathrm{O}$ [Straub et al., 2002]), and transported HFSE and LREE in additon [e.g., Elliott et al., 1997; Class et al., 2000], then the increase in the Neogene Mariana arcs could be attributed to temporay increase of a sediment melt component in source [Bryant et al., 1999]. This interpretation is entirely consistent with the concurrent increase in the HFSE elements, and the decrease in Nd isotope ratios during that period (Figure 14 [Bryant et al., 1999]). Moreover, a direct link between the $\mathrm{K}_{2} \mathrm{O}$ abundance and the amount of sediment melt components in the source might provide an explanation of the different $\mathrm{K}_{4.0}$ characteristics of the Izu Bonin and Mariana arcs [Schmidt et al., 2000; Plank and Kelley, 2001]. In this model, the amount of sediment melt component in source is causally related to the different angle of slab dip (Figure 15). In the Neogene Izu Bonin arc, only slab fluids infiltrate the arc front sources, and hence the $\mathrm{K}_{2} \mathrm{O}$ abundances are lower than in the reararc region, the sources of which are metasomatized by $\mathrm{K}_{2} \mathrm{O}$-rich partial slab melts. Both components are present in the Mariana arc as well, but owing to the steep angle of the subducting slab beneath the Marianas, these components co-mingle prior to reaching the arc source regions. The larger implications of this model - that is currently under investigation [e.g., Plank and Kelley, 2001] - is, that the chemistry of 


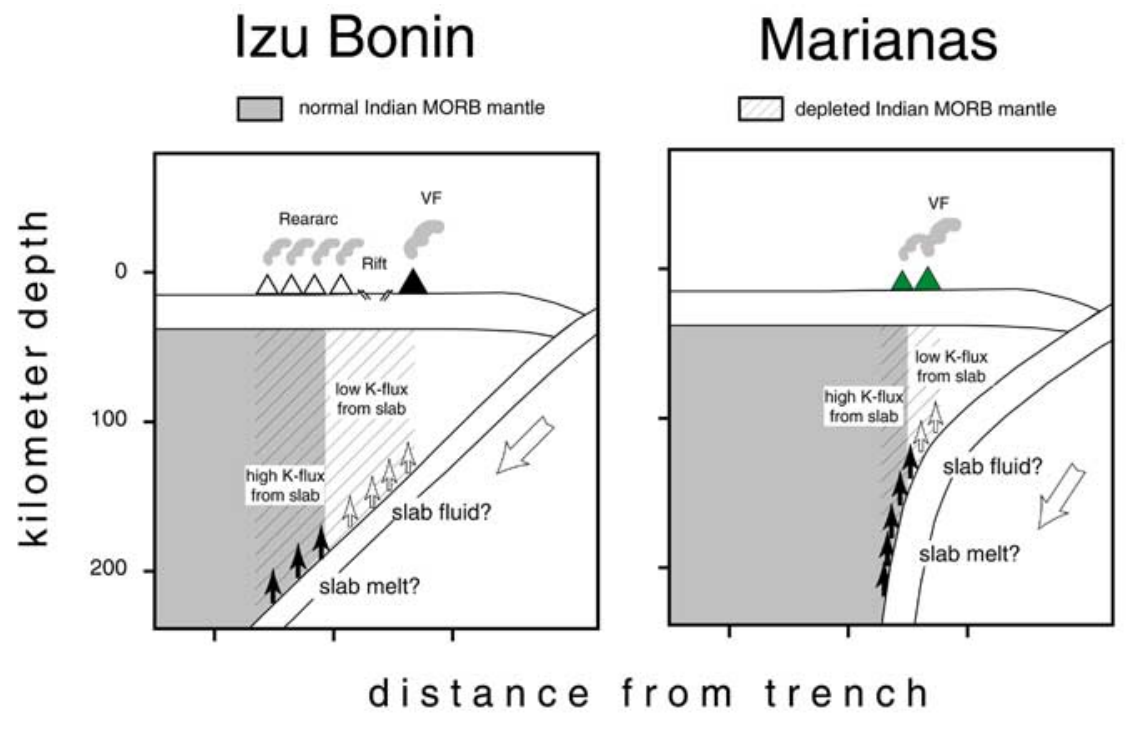

Figure 15. Cartoon illustrating the effect of the variable angle of slab dip on the magnitude of the $\mathrm{K}_{2} \mathrm{O}$ flux from slab into the magma source regions beneath the Izu Bonin and Mariana arcs [Schmidt et al., 2001; Plank and Kelley, 2001]. VF, arc volcanic front (see text for discussion).

$\mathrm{K}_{2} \mathrm{O}$ and other highly incompatible elements of the newly formed arc crust are primarly controlled by the slab flux (i.e. by recycling), whereas juvenile additions from the subarc mantle should play a subordinate role.

\subsection{Transition From Boninitic to Tholeiitic Arc Volcanism}

[26] A striking characteristic of the IBM is the transition from the boninitic and tholeiitic magmas in the early stage of arc evolution, to the later exclusively tholeiitic magmas of the Neogene [e.g., Taylor, 1992]. During the early rift-like setting from $\sim 49$ to $38 \mathrm{Ma}$ - when the boninite magmas were most abundant - the magma production rates might have been exceptionally high $(\sim 120-180$ $\mathrm{km}^{3} / \mathrm{km}$ of arc/Ma [Stern and Bloomer, 1992]. Therefore, a considerable portion of the new IBM crust could have formed during that period [e.g., Taylor, 1992]. (Note the following discussion relies primarly on the samples from the Izu Bonin arc, since the lava and tephra data are much better constrained with respect to analytical quality and age.)

[27] The Eocene and Oligocene IBM boninites and tholeiites have been recovered from various locations in either the forearc region, or the remnant
Palau-Kyushu arc [e.g., Hickey and Frey, 1982; Hickey-Vargas and Reagan, 1987; Hickey-Vargas, 1989]. The two series are intimately associated in space and time (being intercalated at single locations), with no unidirectional developement toward either boninitic or tholeiitic compositions recognizable from the lava data. The intimate association is the more surprising since it is well constrained by major element, trace element and isotope data that the boninitic and tholeiitic series must originate from different mantle sources [Hickey-Vargas and Reagan, 1987; Hickey-Vargas, 1992]. The tholeiitic series are typical arc tholeiites with flat N-MORBlike REE patterns and radiogenic Nd isotope ratios. The tholeiites presumably originate from a depleted Indian MORB mantle that has been metasomatized by a slab component. In contrast, the boninites must have been derived from an extremely depleted peridotite mantle, in order to account for the high $\mathrm{Al}_{2} \mathrm{O}_{3} / \mathrm{TiO}_{2}$ ratios, the high $\mathrm{mg} \#$ numbers and the unusually low HFSE and REE abundances. Moreover, the boninites have distinctive high ratios of $\mathrm{Zr} / \mathrm{Sm}$ and $\mathrm{Hf} / \mathrm{Sm}$ ('positive $\mathrm{Zr}-\mathrm{Hf}$ anomalies', as indicated in Figure 13) and lower ${ }^{143} \mathrm{Nd} /{ }^{144} \mathrm{Nd}$ ratios than their associated tholeiites. Hickey-Vargas [1992] proposed that the intimate vicinity of the two mantle sources are an original feature of the Indian MORB source mantle that 
underlies the IBM. In this model, the Indian astenospheric mantle contains enriched, fusible OIB-like source components since formation. Prior to involvement as arc source mantle, however, melting at the backarc spreading centers may have extracted these enriched components, leaving an residue behind, that consists of depleted MORB mantle (= source of arc tholeiites) and highly refractory components with an unradiogenic, OIB-like $\mathrm{Nd}$ isotope signature (= source of boninites). (Note, $\mathrm{Pb}$ and $\mathrm{Sr}$ isotopes are not considered here, since the positive $\mathrm{Pb}$ and $\mathrm{Sr}$ spikes in the multielement diagrams (Figure 13) suggest that these elements are largely derived from the subducting slab, and hence have little bearing on the wedge development).

[28] However, the comprehensive view of the IBM development provided by the data compilation suggests an alternative model. If the total length of the period of coexisting tholeiitic and boninitic magmatism of $\sim 20$ million years is considered, which is well beyond the range covered by the individual outcrops, it appears that the chemical characteristics typical of boninite magmas disappear gradually with time. This feature is most evident in the $\mathrm{Nd}$ isotope ratios of the Izu Bonin tephra and lavas (Figure 14). Both lavas and tephras indicate a general increase in $\mathrm{Nd}$ isotope ratios with time until the late Oligocene, whereby the highly ressolved tephra trends show significant fluctuations. The increase in $\mathrm{Nd}$ isotopes ratios is paralleled by (1) a general increase in the abundances of the wedge-controlled HFSE and REE elements from $\sim 0.2-0.4$ times N-MORB in the Eocene, to $\sim 0.5-0.8$ times N-MORB in the Oligocene to close to N-MORB abundance in the Neogene Izu VF lavas, and (2) the disappearance of the positive Zr-Hf anomaly (Figure 13). Again, the trace element evolution of the time-averaged lava compositions appears to be reproduced by the tephra, whereby the temporally better ressolved tephras indicate a larger variability. Note that the youngest of three Eocene-Oligocene tephras analysed for trace elements, a rhyolite at $26.3 \mathrm{Ma}$, is more depleted in HREE and has a more pronounced $\mathrm{Zr}$-Hf anomaly than the two older tephras (Figure 13). If the $\mathrm{Nd}$ isotope ratios are taken as



Figure 16. $\mathrm{TiO}_{2}, \mathrm{Al}_{2} \mathrm{O}_{3}, \quad \mathrm{mg} \#$ and $\mathrm{Nd} / \mathrm{Zr}$ versus ${ }^{143} \mathrm{Nd} /{ }^{144} \mathrm{Nd}$ isotope ratios of Izu Bonin lavas. See Table 1 for data sources. IND, Indian MORB source, UDM, ultradepleted mantle. Note that the least radiogenic Eocene Oligocene lavas have the largest $\mathrm{Zr}$ Hf anomalies ( $=$ low $\mathrm{Nd} / \mathrm{Zr}$ ratio), and are most depleted in $\mathrm{TiO}_{2}$ and $\mathrm{Al}_{2} \mathrm{O}_{3}$.

indicator of the temporal change, it shows that the trends of major element oxides is time-dependent as well (e.g., $\mathrm{TiO}_{2}$ and $\mathrm{Al}_{2} \mathrm{O}_{3}$ in Figure 16). $\mathrm{TiO}_{2}$ and $\mathrm{Al}_{2} \mathrm{O}_{3}$ that are both indicative of mantle source enrichments correlate positively with the increas- 
ing $\mathrm{Nd}$ isotopes ratios in the Eocene-Oligocene lavas, forming an array that runs toward the field of the Quaternary Izu VF tholeiites (Figure 16). Moreover, the temporal trends of $\mathrm{Ti}_{4.0}, \mathrm{Si}_{4.0}$, and $\mathrm{mg \#}$ of the Izu Bonin lavas are consistent with a gradual transition from magmas with boninitic characteristics toward purely tholeiitic magmas (Figures 6-8).

[29] These observations suggest that the major element development of the IBM magma is tightly linked to the presence of these two different mantle source domains. Hence, the provenance of these domains is fundamental to understanding the major element chemistry of the IBM. However, unlike the model of Hickey-Vargas [1992] that proposes a single, if heterogenous, source mantle beneath the IBM, the data can also be explained when considering the existence of two different mantle domains that were completely separated at arc initiation. In this model, the ultradepleted subarc mantle with the unradiogenic $\mathrm{Nd}$ isotope ratios existed at arc initation, and then became gradually replaced by the radiogenic Indian MORB mantle during the Eocene and Oliogence.

[30] Mantle convection is the only feasible driving force for such a mantle replacement. Assuming a corner-flow model and an average speed of the convecting upper mantle of $5 \mathrm{~cm} /$ year, a parcel of upper mantle from $\sim 100 \mathrm{~km}$ behind the arc front requires only $\sim 1$ to 3 million years to circle once beneath the arc front. Consequently, the replacement cannot have occurred in a single turnover, but must have been a gradual process, in where the original subarc mantle became gradually infiltrated by 'parcels' of the Indian MORB mantle until the replacement was complete. A gradual replacement readily accounts for the wide range of trace elements and isotopic ratios in the Eocene-Oligocene lavas and tephras, that are best explained by source mixing [e.g., Hickey-Vargas and Reagan, 1987]. Importantly, in a plot of $\mathrm{Nd}$ isotope ratios versus $\mathrm{Zr} / \mathrm{Nd}$, where mixing is linear, the Eocene-Oligocene lavas form - as predicted - a broad negative trend, that extends between the refractory, ultradepleted mantle (UDM in Figure 16) and depleted Indian MORB mantle (IND in Figure 16). The replacement process must have started immediately after arc inception, as is indicated by the tholeiitic basalts and andesites of Hahajima island that are of late Middle Eocene age ( 42-46 Ma) and that have the signatures of Indian MORB (e.g., $\mathrm{TiO}_{2}$ $\sim 0.8-1.2 \mathrm{wt} \% ;{ }^{143} \mathrm{Nd} /{ }^{144} \mathrm{Nd} \sim 0.51300-0.51304$ ) [Taylor and Nesbitt, 1995]. Based on the $\mathrm{Nd}$ isotope profiles (Figure 14), the mantle replacement must have been completed in the late Oligocene or early Miocene.

\subsubsection{The Origin of the Ultradepleted Mantle}

[31] In a previous study, Pearce et al. [1999] argued that the Eocene-Oligocene subarc mantle has had an Indian MORB type signature throughout. This theory builds on the Nd and $\mathrm{Hf}$ ratios of the IBM lavas that appear to plot in the field of Indian MORB rather than in the field of Pacific NMORB [Pearce et al., 1999]. However, the extended data set of Nd-Hf isotopes from MORB and OIB compiled by Chauvel and Blichert-Toft [2001] shows that the discrimination diagram used by Pearce et al. [1999] is ambiguous. In the extended diagram, the Eocene and Oligocene IBM lavas plot in a field that is occupied by Indian, Pacific and Atlantic N-MORB, as well as by some radiogenic intraplate basalts (e.g., Hawaii, Galapagos). Furthermore, a MORB source mantle cannot account for the characteristic $\mathrm{Zr}$-Hf anomaly of the Eocene-Oligocene IBM lavas, given the restricted range of $\mathrm{Nd} / \mathrm{Hf}$, or $\mathrm{Sm} / \mathrm{Hf}$, observed in global MORB (Figure 17). In the $\mathrm{Nd} / \mathrm{Hf}$ versus $\mathrm{Nd}$, and $\mathrm{Sm} / \mathrm{Hf}$ versus Sm diagrams, the Eocene-Oligocene lavas plot mostly outside the field of MORB, whereas the Neogene Izu lavas coincide with MORB.

[32] Mantle peridotites drilled from serpentinite seamounts from the outer IBM forearc have unradiogenic ${ }^{187} \mathrm{Os} /{ }^{188}$ Os-ratios $(0.1193-0.1273)$ that give Proterozoic model ages of 820 to 1230 million years [Parkinson and Pearce, 1998]. Parkinson et al. [1998] proposed that these unradiogenic ${ }^{187} \mathrm{Os} /{ }^{188}$ Os-ratios recorded an ancient melting event, that took place well prior to the entrapment of this material in the Eocene IBM subduction zone. The positive $\mathrm{Zr}-\mathrm{Hr}$ anomalies and the relatively unradiogenic $\mathrm{Nd}$ istopes indicate affinities to 


\section{Izu Bonin lavas}
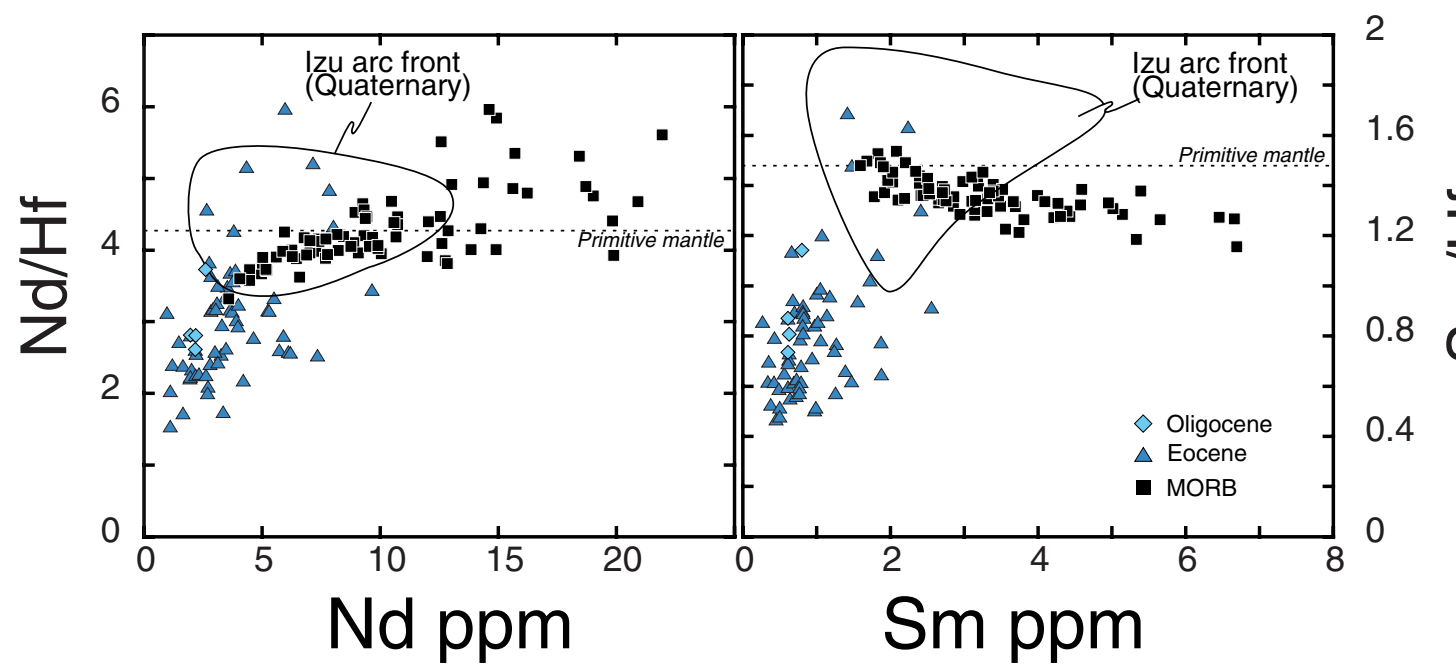

Figure 17. $\mathrm{Nd} / \mathrm{Hf}$ versus $\mathrm{Nd}$ and $\mathrm{Sm} / \mathrm{Hf}$ versus $\mathrm{Sm}$ of Izu Bonin lavas compared to MORB (the MORB array is representative for global MORB as seen from Figures 8c and 8d in Chauvel and Blichert-Toft [2001]). The Eocene and Oligocene Izu Bonin lavas with the positive Zr Hf anomalies (= low Nd/Hf and Sm/Hf ratios) differ clearly from global MORB. The field of the Quaternary Izu Bonin VF overlaps with MORB, although it shows a larger variety. See Table 1 for data sources.

enriched MORB mantle (E-type MORB) or even to the sub-continental lithosphere [e.g., Parkinson and Pearce, 1998; Hickey-Vargas, 1998; Donnelly et al., 2000; Donnelly et al., 2001]. Therefore the ultradepleted mantle could be residual to enriched intraplate volcanism, or possibly to continental volcanism, that took place well before IBM arc initiation. If correct, then it follows that the genesis of the IBM Eocene boninites might be the consequence of the circumstantial presence of such ultradepleted mantle at subduction initiation, and was not related to a later generic process within the Indian MORB source mantle. If such slices of ultradepleted mantle were rare, or become rapidely destroyed in the geodynamic cycle, this might account for the world-wide rarity of boninites.

\subsubsection{Basement-Forming Versus Cone-Building Volcanism}

[33] A puzzling observation is that the mafic and intermediate Eocene-Oligocene tephra glasses of the IBM are exclusively tholeiitic in terms of major elements, in contrast to the co-eval extrusive series. How can there be a linkage between magma chem- istry and eruption style? From the data collected so far, it appears that the extrusion of boninitic magmas is confined to an extensional environment that is similar to slow spreading ridges, and that is unlike any contemporaneous oceanic subduction zone [e.g., Stern and Bloomer, 1992; Taylor, 1992]. By contrast, the earliest mid-Eocene tholeiitic lavas erupt from a stratocone edifice that is constructed within this extensional zone (e.g., Hahajima [Taylor and Nesbitt, 1995]). According to Taylor [1992], ridge-building and cone-building volcanism co-existed for an extended period of time during the late Eocene and Oligocene, before finally a classical arc with tholeiitic stratocones prevailed in the Neogene. Thus, if the tholeiitic magmas preferentially erupt from these stratocone centers, that are bound to erupt explosively as well, the pre-dominantly tholeiitic composition of the tephra might be explained. However, why should the stratocone volcanoes preferentially sample the more fertile, tholeiitic mantle sources? At the present, I can only speculate, that the enriched parcels of the Indian MORB mantle might lead to preferential nodes of melting in the ultradepleted subarc mantle that could maintain the small-volume 
magma plumbing systems of stratocones. In contrast, the ultra-depleted, refractory boninitic mantle source might require the large-scale upwelling associated with ridge formation in order to reach the solidus.

\subsection{The Temporal Constancy of the Other Major Element Oxides}

[34] A remarkable feature of the IBM major element evolution is that they are always arc-like, either being boninitic or tholeiitic, since arc initiation. There is no chemical trend that indicated a gradual transition from MORB-like or OIB-like chemistry to the typical arc chemistry with time. Moreover, aside from the variations related to the two mantle sources, the temporal trends of the other major element oxides remain relatively constant. Such a continuity can only be achieved, if the generic processes of melt formation are equally fundamental as source composition in controlling the major element chemistry of arc magmas. Owing to their elevated $\mathrm{H}_{2} \mathrm{O}$ contents (several $\mathrm{wt} \%$ ), the major element chemistry of arc magmas may differ substantially from anhydrous melts formed from the same mantle sources [e.g., Kushiro, 1990; Hirose, 1997; Blatter and Carmichael, 2001]. Other processes that may affect the major element composition are the tectonic developement, or crustal thickening. Based on the models of McCulloch and Gamble [1991] and Woodhead et al. [1993], a perceptible decrease in $\mathrm{TiO}_{2}$ abundances could be expected during backarc formation, in response to the melt extraction from the mantle at the backarc spreading centers prior to the reaching the arc front. However, none such variations are evident in either the major element record, nor from the trace elements [Bryant et al., 1999]. To the other, the upper plate crust is commonly thought to play a major role in modifiying the composition of mantle melts by either the processes of crustal differentiation, or by controlling the extent of melting [Gill, 1981; Plank and Langmuir, 1988; Leeman, 1983; Hildreth and Moorbath, 1988]. Assuming an initial thickness of the IBM crust of $\sim 6 \mathrm{~km}$ at arc initiation (i.e., average oceanic crust), then the subarc crust must have thickened with time to reach the present thickness of $\sim 20$ to $30 \mathrm{~km}$. As the tephra melts of intermediate compositions appear to originate from the same mantle sources, their temporal trends should provide an excellent means to record chemical changes that occurred in response to gradual crustal thickening. The model of Plank and Langmuir [1988] proposes an inverse relationship between the degree of melting and the crustal thickness. Consequently, as the crust thickens, the $\mathrm{Na}_{2} \mathrm{O}$ and $\mathrm{TiO}_{2}$ in the mantle melts should increase with time, and the $\mathrm{CaO}$ abundance decrease. In the Neogene Mariana arc, an increase of $\mathrm{Na}_{4.0}$ and $\mathrm{Ti}_{4.0}$ at constant $\mathrm{Na}_{2} \mathrm{O} / \mathrm{TiO}_{2}$ in the tephras appears to be coupled with a slight, but perceptible decrease in $\mathrm{Ca}_{4.0}$ with time (Figures 5 and 6). Although these trends seemingly emulate the model of Plank and Langmuir [1988], it must be noted that the $\mathrm{Na}_{4.0}$ (or $\mathrm{Ti}_{4.0}$ ) of the Neogene glasses is not correlated with the $\mathrm{Ca}_{4.0}$ on Harker diagrams. Further, comparable trends are not observed in the Izu Bonin arc. Alternative to the model to Plank and Langmuir [1988], mantle melts might be subject to more intensive crustal processing in thicker crusts. Tamura and Tatsumi [2002] suggested that the dacitic and rhyolitic melts of the Quaternary Izu Bonin arc were partial melts of the middle Izu Bonin crust ( $\sim-12 \mathrm{~km}$ depth), that presumably consists of a tonalite layer [Suheyiro et $a l ., 1996]$. The tonalite itself is proposed to have formed by the intrusion of primary andesite melts in the course of the arc evolution [Tamura and Tatsumi, 2002]. Based on this model, one might predict that the Izu Bonin magmas became more siliceous with time as the volume of the tonalite increases. Concurrently, the contents of $\mathrm{K}_{2} \mathrm{O}$ and $\mathrm{Na}_{2} \mathrm{O}$ should increase, and the contents of $\mathrm{FeO}^{*}$, $\mathrm{MgO}, \mathrm{CaO}$ and $\mathrm{Al}_{2} \mathrm{O}_{3}$ decrease. However, none such trends are observed, either in the corrected or in the uncorrected abundance data (Figures 3-8; auxiliary material). The tephra glasses show that a similar range of basalt to rhyolite compositions existed at all ages, without any recognizable systematic increase in the amount of high-silica tephras at the expense of more mafic glasses. The same is true for the Mariana arc (with the exception of $\mathrm{K}_{2} \mathrm{O}$, see above). A potential explanation for the absence of temporal trends attributable to crustal thickening was that most of the present crustal 


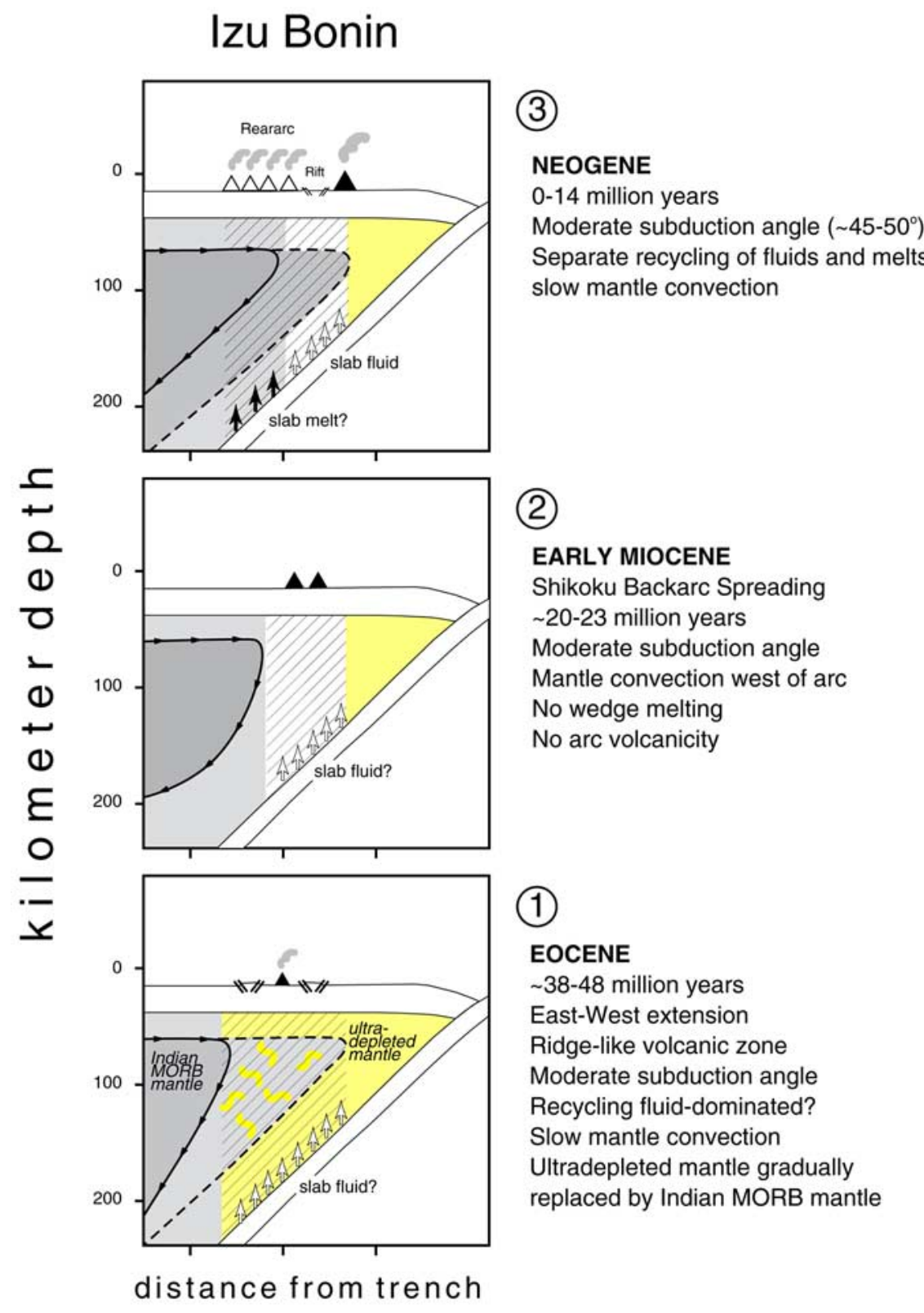

Figure 18. Cartoon depicting three selected stages of the Izu Bonin arc evolution. Yellow color represents the ultradepleted early subarc mantle. Circled numbers refer to Figure 3. See text for discussion.

volume might have generated in the rift-like setting during the 10 million years of arc formation. If the rates crustal growth were much lower afterwards, substantiative effects on the major element chemistry of the arc magmas might not occur. Wathever the actual causes of the comparative constancy of the major element oxides, however, the importance fact is that this constancy suggests that the thickness of the overlying crust is a negligible factor in shaping the major element chemistry of the IBM magmas, relative to the variability inherited from source.

\subsection{An Evolutionary Model of the IBM in Terms of Major Element Chemistry}

[35] Figures 18 and 19 attempt to summarize the data by combining the new results with the existing evolutionary framework of the IBM. 




Figure 19. Cartoon depicting three selected stages of the Mariana arc evolution. Yellow color represents the ultradepleted early subarc mantle. Circled numbers refer to Figure 3. See text for discussion.

Even if several aspects remain speculative at the present, an outline is provided that illustrates the evolutionary models discussed. The basic assumption is that clockwise mantle convection is operative in order to maintain the high temperatures required for mantle melting beneath the arc front [Spiegelman and McKenzie, 1987]. The hot, convecting mantle is fluxed by slab fluids and melts at subarc depths. The double front of the con- vective cell (stippled and solid lines) indicates the horizontal movement of the convecting mantle. Since the Eocene, the ultra-depleted subarc mantle (yellow) is gradually replaced by Indian MORB mantle (dark grey) advected from the western reararc regions. Following van der Hilst and Seno [1993], it is assumed that angle of the Mariana subducting slab steepened with time since subduction initiation. The steeper angle might have 
enabled a faster, more efficient convective mixing of the two mantle domains, perhaps causing the tholeiitic and boninitic series being less disparate in the Mariana arc (Figure 19). The waning (or even interruption) of arc volcanism in the Izu Bonin arc during the early Miocene, concurrent with the Shikoku backarc spreading, is depicted to reflect the temporally displacement of the convecting mantle to the west of the Izu Bonin arc. This event might be related to the retreat of the Izu Bonin trench in the Miocene [van der Hilst and Seno, 1993]. The short period of increased slab melting in the Mariana arc, indicated by the high $\mathrm{K}_{4.0}$, takes place shortly after the termination of backarc spreading in the Parece Vela basin. Possibly, the change from a period of across-arc extension during backarc spreading, to later across-arc compression occurred due to the enforced eastward movement of the lithosphere that has been formed at the backarc spreading centers. The compressional regime might have raised the slab surface temperatures, by either increasing the rate of shear heating along the subduction shear zone [e.g., Peacock, 1996], or by moving the hotter part of the mantle wedge closer to the subducting slab. After completion of the subarc mantle replacement by the end of the Oligocene, the IBM appears to have entered a steady state, as envisioned by Hochstaedter et al. [2001]. This steady state is characterized by the continuous advection of Indian MORB mantle from the reararc, that is continuously fluxed by hydrous slab components [e.g., Hochstaedter et al., 2000, 2001].

\section{Summary and Conclusions}

[36] The principal conclusions of this study are as follows:

1. Distal fallout tephra are an excellent tool in obtaining a temporally highly resolved record of the major element evolution of volcanic arcs. However, the tephra fallout is linked to explosive volcanism and does not record the dominantly extrusive periods of arc formation. Therefore, establishing a comprehensive framework of the major element evolution for the IBM requires both the tephra and lava chemistry.
2. The $\mathrm{K}_{2} \mathrm{O}$ variability of the IBM magmas appears to be controlled by additions from the slab rather than by variation in the extent of melting, or a heterogenous mantle source.

3. All other major elements are controlled by the composition and processes within the mantle wedge. It is proposed that the transiton from boninitic to tholeiitic volcanism during the Eocene and Oligocene is the result of a large scale replacement of the subarc mantle wedge.

4. The effects of crustal thickening on the arc major element chemistry appear to be small relative to variations induced by mantle source heterogeneities.

5. The multitude of source compositions and processes that are operative during the 49 million years of IBM history will result in significant heterogeneity of the newly formed arc crust.

\section{Acknowledgments}

[37] The 782A tephra was made available through the Ocean Drilling Program (College Station/TX). I thank Jongman Lee for an electronic copy of the Mariana tephra data, and the support staff of the Lamont Doherty Earth Observatory for help in collecting the other Izu Bonin tephra data from various literature sources. R. Arculus, Y. Tamura and two unknown reviewers are thanked for constructive journal reviews, and W. White and Y. Tatsumi for very helpful editorial comments. All these efforts improved the manuscript considerably. Funding by the "Deutsche Forschungsgemeinschaft' (Str 441/3 and Str 441/4) is gratefully acknowledged."

\section{References}

Arculus, R. J., and A. L. Bloomfield, Major-element chemistry of ashes from sites 782, 784, and 786 in the Bonin Forearc, Proc. Ocean Drill. Program Sci. Results, 125, 277-292, 1992.

Arculus, R. J., J. A. Pearce, B. J. Murton, and S. R. vdLaan, Igneous stratigraphy and major-element geochemistry of Holes 786A and 786B, Proc. Ocean Drill. Program Sci. Results, 125, 143-168, 1992.

Arculus, R. J., J. B. Gill, H. Cambray, W. Chen, and R. J. Stern, Geochemical evolution of arc systems in the Western Pacific: The ash and turbidite record recovered by drilling, in Active Margins and Marginal Basins of the Western Pacific, Geophys. Monogr. Ser, vol. 88, edited by B. Taylor and J. Natland, pp. 45-65, AGU, Washington, D.C., 1995.

Armstrong, R. L., and G. T. Nixon, Chemcial and Sr-isotopic compositons of igneous rocks from Deep Sea Drilling Project Legs 59 and 60, Init. Rep. Deep Sea Drill. Proj., 59, 719-727, 1980. 
Blatter, D. L., and I. S. E. Carmichael, Hydrous phases equilibria of a Mexican high-silica andesite: A candidate for a mantle origin?, Geochim Cosmochim Acta, 65, 40434065, 2001.

Bloomer, S. H., R. J. Stern, and N. C. Smoot, Physical volcanology of the submarine Mariana and Volcano arcs, Bull. Volcanol., 51, 210-224, 1989a.

Bloomer, S. H., R. J. Stern, E. Fisk, and C. H. Geschwind, Shoshonitic volcanism in the northern Mariana arc, J. Geophys. Res., 94, 4469-4496, 1989b.

Bloomer, S. H., B. Taylor, C. J. MacLeod, R. J. Stern, P. Fryer, J. W. Hawkins, and L. Johnson, Early arc volcanism and the ophiolite problem: a perspective from drilling in the Western Pacific, in Active Margins and Marginal Basins of the Western Pacific, Geophys. Monogr. Ser., vol. 88, edited by B. Taylor and J. Natland, pp. 1-3, AGU, Washington, D. C., 1995.

Bougault, H., R. C. Maury, M. ElAzzouzi, J. L. Joron, J. Cotton, and M. Treuil, Tholeiites, basaltic andesites and andesites form Leg 60 Sites: Geochemistry, mineralogy and low partition coefficient elements, Init. Rep. Deep Sea Drill. Proj., 60, 657-677, 1981.

Bryant, C. J., R. J. Arculus, and S. M. Eggins, Laser ablationinductively coupled plasma-mass spectrometry and tephras: A new approach to understanding arc magma genesis, Geology, 27, 1119-1122, 1999.

Chauvel, C., and J. Blichert-Toft, A hafnium isotope and trace element perspective on melting of the depleted mantle, Earth Planet. Sci. Lett., 190, 137-151, 2001.

Class, C., D. M. Miller, S. L. Goldstein, and C. H. Langmuir, Distinguishing melt and fluid subduction components in Umnak volcanics, Aleutian Arc, Geochem. Geophys. Geosyst., 1, Paper number 1999GC000010, 2000.

Cosca, M. A., R. J. Arculus, J. A. Pearce, and J. G. Mitchell, ${ }^{40} \mathrm{Ar} /{ }^{39} \mathrm{Ar}$ and $\mathrm{K}-\mathrm{Ar}$ geochronological age constraints for the inception and early evolution of the Izu Bonin-Mariana arc system, The Island Arc, 7, 579-595, 1998.

Crawford, A. J., T. J. Fallon, and D. H. Green, Classification, petrogenesis and tectonic setting of boninites, in Boninites and Related Rocks, edited by A. J. Crawford, pp. 2-44, Unwin Hyman Publ., London, 1989.

Dobson, P. F., The petrogenesis of boninite: A field, petrologic, and geochemical study of the volcanic rocks of Chichi-jima, Bonin Islands, Japan, Ph.D., Stanford Univ., Stanford, Calif., 1986.

Donnelly, K., C. H. Langmuir, and S. L. Goldstein, Constraints on the generation of enriched mid-ocean ridge basalts, Eos Trans. AGU, 81(48), Fall Meet. Suppl., F1281, 2000.

Donnelly, K., C. H. Langmuir, S. L. Goldstein, and A. LaGatta, The origin of alkali and ocean island basalts: Contradictions and solutions, Eos Trans $A G U$, 82(47), Fall Meet. Supp., F1402, 2001.

Elliott, T., T. Plank, A. Zindler, W. White, and B. Bourdon, Element transport from subducted slab to juvenile crust at the Mariana arc, J. Geophys. Res., 102, 14,991-15,019, 1997.

Fryer, P., J. A. Pearce, and L. B. Stokking (Eds.), Proceeding of Ocean Drilling Program, Initial Reports, vol. 125, 1092 pp., Ocean Drilling Program, College Station, Tex., 1990.

Fujioka, K., Y. Matsuo, A. Nishimura, M. Koyama, and K. S. Rodolfo, Tephras of the Izu Bonin Forearc (Sites 787, 792, 793), Proc. Ocean Drill Program Sci. Res., 126, 47-74, 1992b.

Garbe-Schönberg, C. D., Simultaneous determination of thirtyseven trace elements in twenty-eight international rock standards by ICP-MS, Geostand. Newsl., 17, 81-97, 1993.

Gill, J., Orogenic Andesites and Plate Tectonics, 390 pp., Verlag-Springer, New York, 1981.

Gill, J. B., R. N. Hiscott, and P. Vidal, Turbidite geochemistry and evolutions of the Izu Bonin arc and continents, Lithos, 33, 135-168, 1994.

Hickey, R. L., and F. Frey, Geochemical characteristics of boninite series volcanics: Implications for their sources, Geochim. Cosmochim. Acta, 46, 2099-2115, 1982.

Hickey-Vargas, R., Boninites and tholeiites from DSDP Site 458, Mariana forearc, in Boninites and Related Rocks, edited by A. J. Crawford, pp. 340-356, Unwin Hyman Publ., London, 1989.

Hickey-Vargas, R., A refractory HIMU component in the sources of island-arc magmas, Nature, 360, 57-59, 1992.

Hickey-Vargas, R., Geochemical characteristics of oceanic island basalts from the Philippine Sea Plate: Implications of the sources of East Asia plate margins and intraplate basalts, in Mantle Dynamics and Plate Interactions in East Asia, Geophys. Monogr. Ser., vol. 27, edited by M. F. J. Flower et al., pp. 365-384, AGU, Washington, D.C., 1998.

Hickey-Vargas, R., and M. K. Reagan, Temporal variation of isotope and rare earth element abundances in volcanic rocks from Guam: Implications for the evolution of the Mariana Arc, Contrib. Mineral. Petrol., 97, 497-508, 1987.

Hildreth, W., and S. Moorbath, Crustal contributions to arc magmatism in the Andes of Central Chile, Contrib. Mineral. Petrol., 98, 455-489, 1988.

Hirose, K., Melting experiments on lherzolite KLB-1 under hydrous conditions and generation of high-magnesian andesitic melts, Geology, 25(1), 42-44, 1997.

Hochstaedter, A. F., J. B. Gill, B. Taylor, O. Ishizuka, M. Yuasa, and S. Morita, Across-arc geochemical trends in the Izu Bonin arc: Constraints on source composition and mantle melting, J. Geophys. Res., 105, 495-512, 2000.

Hochstaedter, A. G., J. B. Gill, R. Peters, P. Broughton, P. Holden, and B. Taylor, Across-arc geochemical trends in the Izu Bonin arc: Contributions from the subducting slab, Geochem. Geophys. Geosys., 2, Paper number 2000GC000105, 2001.

Jackson, M. C., Petrology and petrogensis of recent submarine volcanics from the northern the Mariana arc and backarc basin, Ph.D. Thesis, Univ. of Hawaii, Honolulu, 1989.

Johnson, M. C., and T. Plank, Dehydration and melting experiments constrain the fate of subducted sediment, Geochem. Geophys. Geosys., 1, Paper number 1999GC000014, 1999.

Kelemen, P. B., Genesis of high Mg\# andesites and the continental crust, Contrib. Mineral. Petrol., 120, 1-19, 1995.

Kelemen, P. B., N. Shimizu, and T. Dunn, Relative depletion of niobium in some arc magmas and the continental crust: 
Partioninig of $\mathrm{K}, \mathrm{Nb}$, La and Ce during melt/rock reaction in the upper mantle, Earth Planet. Sci., 120, 111-134, 1993.

Kuroda, N., K. Shiraki, and H. Urano, Ferropigeonite quartz dacites from Chichi-jima, Bonin Islands: Latest differentiates from boninite-forming magma, Contrib. Mineral. Petrol., 100, 129-138, 1988.

Kushiro, I., Partial melting of mantle wedge and evolution of island arc crust, J. Geophys. Res., 95, 15,929-15,939, 1990.

Langmuir, C. H., E. M. Klein, and T. Plank, Petrological systematics of mid-ocean ridge basalts: Constraints on melt generation beneath ocean ridges, in Mantle Flow and Melt Generation at Mid-Ocean Ridges, edited by J. P. Morgan, D. K. Blackman, and J. M. Sinton, pp. 183-280, AGU, Washington, D.C., 1992.

Langmuir, C. H., Y. Zhang, B. Taylor, T. Plank, J. Rubenstone, and A. Schmidt, Petrogenesis of Torishima and adjacent volcanoes of the Izu Bonin arc: One end member of the global spectrum of arc basalts compositions, Contrib. Mineral. Petrol., in press, 2002.

Lee, J. M., R. J. Stern, and S. H. Bloomer, Forty million years of magmatic evolution in the Mariana arc: The tephra record, J. Geophys. Res., 100, 17,671-17,687, 1995.

Leeman, W. P., The influence of crustal structure on compositions of subduction-related magmas, J. Volcanol. Geotherm. Res., 18, 561-588, 1983.

Lin, P. N., R. J. Stern, and S. H. Bloomer, Shoshonitic volcanism in the northern Mariana arc, 2, Large-ion lithophile and rare earth element abundances: Evidence for the source of incompatible element enrichments in intraoceanic arcs, J. Geophys. Res., 94, 4497-4514, 1989.

Lin, P. N., R. J. Stern, J. Morris, and S. H. Bloomer, Nd- and Sr-isotopic compositions of lavas from the northern Mariana and southern Volcano arcs: Implications for the origin of island arc melts, Contrib. Mineral. Petrol., 105, 381-392, 1990.

McCulloch, M. T., and J. A. Gamble, Geochemical and geodynamical constraints on subduction zone magmatism, Earth Planet. Sci. Lett., 102, 358-374, 1991.

Meijer, A., and M. Reagan, Origin of $\mathrm{K}_{2} \mathrm{O}-\mathrm{SiO}_{2}$ trends in volcanoes of the Mariana arc, Geology, 11, 67-71, 1983.

Metrich, N., and R. Clochiatti, Melt inclusion investigation of the volatile behavior in historc alkali basaltic magma of Etna, Bull. Volcanol., 51, 185-198, 1989.

Murton, B. J., D. W. Peate, R. J. Arculus, J. A. Pearce, and S. R. van der Laan, Trace-element geochemistry of volcanic rocks from Site 786: The Izu Bonin forarc, Proc. Ocean Drill. Program Sci. Results, 125, 211-235, 1992.

Niu, Y., and Y. Batiza, Trace element evidence from seamounts for recycled oceanic crust in the Eastern Pacific mantle, Earth Planet. Sci. Lett., 148, 471-483, 1997.

Parkinson, I. J., and J. A. Pearce, Peridotites from the Izu Bonin-Mariana Forearc (ODP Leg 125): Evidence for mantle melting and melt-mantle interaction in a supra-subduction zone setting, J. Petrol., 39, 1577-1688, 1998.

Peacock, S. M., Thermal and petrologic structure of subduction zones, in Subduction: Top to Bottom, Geophys. Monogr. Ser., vol. 96, edited by G. E. Bebout et al., pp. 119-133, AGU, Washington, D.C., 1996.
Pearce, J. A., M. F. Thirlwall, G. Ingram, B. J. Murton, R. J. Arculus, and S. R. van der Laan, Isotopic evidence for the origin of boninites and related rocks drilled in the Izu Bonin (Ogasawara) forearc, Leg 125, Proc. Ocean Drill. Program Sci. Results, 125, 237-261, 1992.

Pearce, J. A., P. D. Kempton, G. M. Nowell, and S. R. Noble, Hf-Nd element and isotope perspective on the nature and provenance of mantle and subduction zone components in Western Pacific arc-basin systems, J. Petrol., 40, 15791611, 1999.

Plank, T., Mantle melting and crustal recyling in subduction zones, Ph.D. thesis, Columbia Univ., New York, 1993.

Plank, T., and K. Kelley, Contrasting sediment input and output at the Izu and Mariana subduction factories, Eos Trans. $A G U$, 82(47), Fall Meet. Suppl., F1155, 2001.

Plank, T., and C. H. Langmuir, An evaluation of the global variations in the major element chemistry of arc basalts, Earth Planet. Sci. Lett., 90, 349-370, 1988.

Plank, T., and C. H. Langmuir, Tracing trace elements from sediment input to volcanic output at subduction zones, Nature, 362, 739-743, 1993.

Prouteau, G., B. Scaillet, M. Pichavant, and R. Maury, Evidence for mantle metasomatism by hydrous silicic melts derived from the subducted oceanic crust, Nature, 410, 197-200, 2001.

Reagan, M. K., and A. Meijer, Geology and geochemistry of early arc-volcanic rocks from Guam, Geol. Soc. Am. Bull., 95, 701-713, 1984.

Rodolfo, K. S., R. U. Solidum, A. Nishimura, Y. Matsuo, and K. Fujioka, Major-oxide stratigraphy of glass shards in volcanic ash layers of the Izu Bonin arc-backarc sites (sites 788/ 789 and 790/791), Proc. Ocean Drill. Program Sci. Results, 126, 505-517, 1992.

Rudnick, R., Making continental crust, Nature, 378, 571-578, 1995.

Schmidt, A., Temporal and spatial evolution of the Izu Island Arc, Japan, in terms of $\mathrm{Sr}-\mathrm{Nd}-\mathrm{Pb}$ isotope geochemistry, Doctoral thesis, Christian-Albrecht-Universität, Kiel, 2001. (Available at http://e-diss.uni-kiel.de/KielerDissonline.html) Schmidt, A., S. M. Straub, K. A. Hoernle, C. H. Langmuir, A. G. Hochstaedter, and J. B. Gill, Causes of geochemical differences between the adjacent Izu and Mariana Arcs, West Pacific, IAVCEI General Assembly, Bali, Indonesia, 2000.

Schmidt, M. W., Experimental constraints on recycling of potassium from subducted oceanic crust, Science, 272, 1927-1929, 1996.

Sharaskin, A. Y., Petrography and geochemistry of basement rocks from five Leg 60 sites, in Inital Rep. Deep Sea Drill. Proj., 60, 647-656, 1981.

Shimizu, H., H. Sawatari, Y. Kawata, P. N. Dunkley, and A. Masuda, Ce and $\mathrm{Nd}$ isotope geochemistry on island arc volcanic rocks with negative Ce anomaly: Existence of sources ith concave REE pattern in the mantle beneath the Solomon and Bonin island arcs, Contrib. Mineral. Petrol., 110, 242-252, 1992.

Spiegelman, M., and D. McKenzie, Simple 2-D models for melt extraction at mid-ocean ridges and island arcs, Earth Planet. Sci. Lett., 83, 137-152, 1987. 
Stern, R. J., and S. H. Bloomer, Subduction zone infancy: Examples from the Eocene Izu Bonin-Mariana and Jurassic California arcs, Geol. Soc. Am. Bull., 104, 1621-1636, 1992.

Stern, R. J., M. C. Jackson, P. Fryer, and E. Ito, O, Sr, Nd and $\mathrm{Pb}$ isotopic compositions of the Kasuga Cross-Chain in the Mariana Arc: A new perspective on the K-h-relationship, Earth Planet. Sci. Lett., 119, 459-475, 1993.

Stolper, E., and S. Newman, The role of water in the petrogenesis of Mariana trough magmas, Earth Planet. Sci. Lett., 121, 293-325, 1994.

Straub, S. M., Contrasting compositions of Mariana Trough fallout tephra and Mariana Island arc volcanics: A fractional crystallization link, Bull. Volcanol., 57, 403-421, 1995.

Straub, S. M., Miocene to Quarternary evolution of the Izu Bonin island arc, Eos Trans. $A G U, 77(46)$, Fall Meet. Suppl., F842, 1996.

Straub, S. M., and G. D. Layne, The systematics of boron isotopes in Izu arc front volcanic rocks, Earth Planet. Sci. Lett., 198, 25-39, 2002a.

Suheyiro, K., N. Takahashi, Y. Ariie, Y. Yokoi, R. Hino, M. Shinohara, T. Kanazawa, N. Hirata, H. Tokuyama, and A. Taira, Continental crust, crustal underplating, and low-Q upper mantle beneath an oceanic island arc, Science, 272, 390-392, 1996.

Sun, C. H., and R. J. Stern, Genesis of Mariana shoshonites: Contribution of the subduction component, J. Geophys. Res., 106, 589-608, 2001.

Sun, S. S., and W. F. McDonough, Chemical and isotopic systematics of oceanic basalts: implications for mantle composition and processes, in Magmatism in the Ocean Basins, edited by A. D. Saunders and M. J. Norry, pp. 313-345, 1989.

Tamura, Y., and Y. Tatsumi, Remelting of an andesitic crust as a possible origin for rhyolitic magma in oceanic arcs: An example from the Izu Bonin Arc, J. Petrol., 43, 10291047, 2002.

Tatsumi, Y., M. Murasaki, and S. Nohda, Across-arc variation of lava chemistry in the Izu Bonin Arc: Identification of subduction components, J. Volcanol. Geotherm. Res., 49, 179-190, 1992.

Taylor, B., Rifting and the volcanic-tectonic evolution of the Izu Bonin-Mariana Arc, Proc. Ocean Drill. Program Sci. Results, 126, 627-651, 1992.

Taylor, B., et al. (Eds), Proceedings of the Ocean Drilling Program, Initial Report, vol. 126, 1002 pp., Ocean Drill. Program, College Station Tex., 1990.

Taylor, R. N., and R. W. Nesbitt, Arc volcanism in an extensional regime at the initiation of subduction: A geochemical study of Hahajima, Bonin Islands, Japan, in Volcanism Associated with Extension at Consuming Plate Margins, edited by J. L. Smellie, Geol. Soc. Spec. Publ., 81, 115-134, 1995.

Taylor, R. N., and R. W. Nesbitt, Isotopic characteristics of subduction fluids in an intra-oceanic setting, Izu Bonin-Arc, Japan, Earth Planet. Sci. Lett., 164, 79-98, 1998.

Taylor, R. N., H. Lapierre, P. Vidal, R. W. Nesbitt, and I. W. Croudace, Igneous geochemistry and petrogenesis of the Izu Bonin Forearc Basin, Proc. Ocean Drill. Program Sci. Results, 126, 405-430, 1992.

Taylor, R. N., R. W. Nesbitt, P. Vidal, R. S. Harmon, B. Auvray, and I. W. Croudace, Mineralogy, chemistry, and genesis of the Boninite series volcanics, Chichijima, Bonin Island, Japan, J. Petrol., 35, 577-617, 1994.

Umino, S., Magma mixing in boninite sequence of Chichijima, Bonin Islands, J. Volcanol. Geotherm. Res., 29, 125-157, 1986.

Umino, S., and E. Yoshizawa, Petrologoy of ultramafic xenoliths from Kishyuku Lava, Fukue-jima, Southwest Japan, Contrib. Mineral. Petrol., 124, 154-166, 1996.

van der Hilst, R., and T. Seno, Effects of relative plate motion on the deep structure and penetration depth of slabs below the Izu Bonin and Mariana island arcs, Earth Planet. Sci. Lett., 120, 395-407, 1993.

van der Hilst, R. D., E. R. Engdahl, W. Spakman, and G. Nolet, Tomographic imaging of subducted lithosphere below northwest Pacific island arcs, Nature, 353, 37-43, 1991.

Wood, D. A., N. G. Marsh, J. Tarney, J. L. Joron, P. Fryer, and M. Treuil, Geochemistry of igneous rocks recovered from a transect across the Mariana trough, arc, forearc, and trench, sites 453 through 461, Deep Sea Drilling Project Leg 60, Initial Rep. Deep Sea Drill. Proj., 60, 611646, 1981.

Woodhead, J. D., The origin of geochemical variations in Mariana lavas: A general model for petrogenesis in intraoceanic island arcs?, J. Petrol., 29, 805-830, 1988.

Woodhead, J. D., Geochemistry of the Mariana arc (western Pacific): Source composition and processes, Chem. Geol., 76, 1-24, 1989.

Woodhead, J. D., S. Eggins, and J. Gamble, High field strength and transition element systematics in island arc and back-arc basin basalts: evidence for multi-phase extraction and a depleted mantle wedge, Earth Planet. Lett., 114, 491-504, 1993.

$\mathrm{Xu}, \mathrm{Y}$, and S. W. Wise, Middle Eocene to Miocene calcareous nannofossils of Leg 125 from the western Pacific Ocean, Proc. Ocean Drill. Program Sci. Results, 125, 43-70, 1992. 